\title{
A OBRA JURIDICA DO PROFESSOR WALDEMAR FERREIRA \\ (1913 a 1950)
}




\section{3}

1. Apelação Civel. - Tribunal da Relação de Minas Gerais. Comarca de Jaguari. João Tertuliano de Oliveira vs. Américo Corrêa Marzagão. Acórdão de 10 de janeiro e de 3 de junho de 1914, na apelação n. 3.236 (Revista Forense, de Belo Horizonte, vol. 23, pág. 100; e Revista do Supremo Tribunal Federal, do Rio de Janeiro, vol. 1, primeira parte, pag. 260). 36 págs. Tip. da Casa Minerva. São Paulo, 1913.

\section{4}

2. Apelação Comercial. - Juizo de Direito da Primeira Vara Civel da Capital de São Paulo. Distrito de Santa Cecilia. Serafim Fernandes vs. F. Armando \& Cia. 17 págs. Tip. da Casa Minerva. São Paulo, 1914.

\section{5}

3. Agravo n. 7.634. - Tribunal de Justiça de São Paulo. Comarca de Araraquara. Stylita Ferreira \& Cia. vs. Januario Judice. Acórdão de 7 de junho de 1915 (Revista dos Tribunais, de São Paulo, vol. 14, pág. 126). 25 págs. Tip. do Instituto Cooperativo Familistário de São Paulo.

4. Agravo n. 7.647. - Tribunal de Justiça de São Paulo. Comarca de Araraquara. Stylita Ferreira \& Cia. vs. Januario 
Judice. Acórdão de 31 de maio de 1915 (Revista dos Tribunais, de São Paulo, vol. 15, pág. 20). 7 pags. Tip. do Instituto Cooperativo Familistário de São Paulo.

5. Apelação Civel n. 7.540. - Tribunal de Justiça de São Paulo. Comarca de Piracaia. Jacinto Osorio vs. Boanerges da Cunha Freire. Acordão de 13 de julho de 1915 (Revista dos Tribunais, de São Paulo, vol. 15, pag. 192). 25 pags. Tip. do Instituto Cooperativo Familistário de São Paulo.

6. Apelação Civel n. 7.909. - Tribunal de Justiça de São Paulo. Comarca de Santos. Herm Stoltz \& Cia. e outros na falência de Correa, Duarte \& Cia. Acórdão de 10 de setembro de 1918 (Revista dos Tribunais, de São Paulo, vol. 27, pág. 234). 17 págs. Tip. do Instituto Cooperativo Familistário de São Paulo.

7. Agravo n. 7.766. - Tribunal de Justiça de São Paulo. Comarca do Amparo. Thomaz Pimentel vs. Massa falida de Domingos Nunes. Acórdão de 26 de agosto de 1915 (Revista dos Tribunais, de São Paulo, vol. 15, pág. 98). 8 págs. Tip. do Instituto Cooperativo Familistário de São Paulo.

8. Agravo n. 7.761. - Tribunal de Justiça de São Paulo. Comarca da Franca. Massa falida de Sergino de Oliveira e Souza vs. Gremio Literário Francano. Acórdão de 9 de agosto de 1915 (Revista dos Tribunais, de São Paulo, vol. 15, pág. 15). 14 págs. Tip. do Instituto Familistário de São Paulo.

9. O penhor sôbre fundos de comércio. - Tribunal de Justiça de São Paulo. Comarca do Amparo. Agravo n. 
7.949. Massa falida de Domingos Nunes vs. Dr. Thomaz Pimentel. Acórdão de 13 de dezembro de 1915 (Revista dos Tribunais, de São Paulo, vol. 18, pág. 14). 38 págs. São Paulo, 1915.

\section{6}

10. Uma questão possessória. - Juizo de Direito da Segunda Vara Civel e Comercial da Comarca de São Paulo. Major Teófilo Ferreira de Almeida vs. Banco Cooperativo Comercial de São Paulo. 20 págs. Tip. da Casa Minerva. São Paulo, 1916.

11. O direito de edificar e sua regulamentação pela Municipalidade. - Tribunal de Justiça de São Paulo. Comarca de Baurú. Apelação Civel n. 8.498. Câmara Municipal de Baurủ vs. João Ferreira de Oliveira. Acórdão de 16 de fevereiro de 1916 (Revista dos Tribunais, de São Paulo, vol. 21, pág. 126). 18: págs. Oficinas Gráficas da Revista de Comércio e Indústria. São Paulo, 1916.

12. Contra uma concordata. - Tribunal de Justiça de São Paulo. Comarca de Jundiai. Agravo n. 8.673. Sociedade de Produtos Quimicos L. Queiroz vs. Pedro Ferrari. 16 pags. Oficinas Gráficas da Revista de Comércio e Indústria. São Paulo, 1917.

\section{7}

13. Da convocacão de credores. - Tribunal da Relação de Minas Gerais. Comarca de Monte Santo. Agravo n. 1.481. Araujo Costa \& Cia. vs. Aristoteles Goulart. Acórdão de 7 de março de 1917 (Revista Forense, de Belo Horizonte, vol. 28, pág. 58). 22 págs. Oficinas Gráficas da Revista de Comércio e Industria. São Paulo, 1917. 
14. Da hipoteca na falência. - Tribunal de Justiça de São Paulo. Comarca de Barretos. Apelação Civel n. 8.682. Miguel Salim Aidar vs. Massa falida de Alexandre José Aidar. Acórdão de 14 de dezembro de 1917 e de 2 de dezembro de 1919 (Revista dos Tribunais, de São Paulo, vol. 24, pág. 310, e vol. 33, pág. 432). 12 págs. Oficinas Gráficas da Revista de Comércio e Industria. São Paulo, 1917.

\section{8}

15. A posse do "Barreiro". - Tribunal de Justiça de São Paulo. Comarca de Baurú. Embargos n. 9.390. João Rodrigues Maia vs. Coronel Joaquim de Toledo Pisa e Almeida. 24 págs. Oficinas Gráficas da Revista de Comércio e Industria. São Paulo, 1918.

I. Sôbre êste opúsculo, deu o Diario Español, de São Paulo, de 10 de fevereiro de 1919, a seguinte notícia:

"Hemos recibido un interesante folleto en el que el ilustre abogado Dr. Waldemar Ferreira, ha reunido las razones de apelación y sustentación de embargos interpuestos ante el Tribunal de Justiça de San Pablo para que se confirme la posesión del "Barreiro", situado en el municipio de Pirajuhy, comarca de Baurú, reclamada por João Rodrigues Maia, su verdadero proprietario.

"Son los embargados, el coronel Joaquim de Toledo Piza y Almeida, su mujer y otros, quienes sôbre su pretendida propriedade dieron lugar al litigio, mandandi establecerse en terrenos del "Barreiro" á empleados suyos que cometieron diversas depredaciones.

"El notable abogado doctor Waldemar Ferreira, en su alegación, conseguió rebatir, uno por uno, los argumentos de los contendores de su cliente, aduciendo tal cantidad de documentos y de hechos probatorios y de la legítima 
propriedad del "Barreiro", que no dejan lugar á duda de los derechos impetrados por João Rodrigues Maia.

"Constituye su luminoso informe, una compilación de datos y testimonios, arrancados ide los que presenta la parte contraria, cuyas deduciones, producto de un profundo análisis y acabado estudio de las fuentes del Derecho, delatan al Dr. Waldemar Ferreira, como jurisconsulto de gran talla.

"Con rara clarividencia, se retrotrae al primer poseedor de la hacienda "Barreiro" y derivando la cuestión hasta el momento del litigio, demuestra con lógica irrebatible que aquellos bienes, perfectamente delimitados, comprobados y reconocidos desde hace 30 años, no pueden ser propriedad de otro, que de Rodrigues Maia, embargante, en cuyo nombre sustenta en sus derechos y apela al Tríbunal para que se le reconfirmen.

"El documento presentado por el Dr. Waldemar Ferreira es, en suma, una prueba tan concluyente, del verdadero valor y sabiduría del ilustde abogado, en la interpretación del derecho civil, que el Tribunal encargado de fallar su causa, reconocerá la justicia en que se inspira para demandarla.

"Felicitamos calorosamente, á su autor alto exponente de la jurisprudencia brasileña."

I. Na A Republica, de Natal, Estado do Rio Grande do Norte, de 20 de fevereiro de 1919, publicou Alberto ROSELLI a seguinte nota bibilográfica:

"O ilustrado Dr. Waldemar Ferreira, um dos mais notáveis advogados do fôro de São Paulo e eminente professor da Universidade daquele Estado, teve a bondade que sobremodo nos penhorou, de ofertar-nos um nítido folheto contendo as suas eruditas razões de apelação e sustentação de embargos em uma debatida questão denominada "A posse do Barreiro".

"O trabalho do talentoso jurisperito é como todos os seus lavores uma peça digna de leitura pela clareza da exposição e substância dos argumentos inivocados e desenvolvidos com a mais perfeita e rigorosa observância dos principios consagrados na doutrina, na jurisprudência e na legislação. 
"O Dr. Waldemar Ferreira costuma publicar todos os seus trabalhos forenses com $o$ que presta inestimável serviço às letras juridicas enriquecendo-as de um modo digno de encômios.

"Em todos êles deixa transparecer os primores de sua inteligência e cultura, que justamente lhe têm valido o merecido renome de que goza na grande capital paulista, onde sua banca de advogado é das mais procuradas na certeza de ser encontrado na pessoa do distinto causídico um estrênuo e dedicado defensor da verdāde e do direito, que sabe esforçar-se, sem especulações e sem fancaria, para fazer sempre triunfar em todo o seu esplendor a sua manifestação suprema de justiça”.

16. Da exclusão de condómino, em ação divisória, por abandono de direito. - Tribunal de Justiça de São Paulo. Comarca de Serra Negra. Apelação civel n. 9.401. Herdeiros do Coronel José Inácio Teixeira vs. Pedro e Natale Mazzucato. Acórđãos de 10 de julho de 1919 e de 9 de março de 1920 (Revista dos Tribunais, de São Paulo, vol. 30, pág. 270, e vol. 34, pág. 226). 15 págs. Casa Pindorama. Amparo, 1918.

17. Do registro de firma para o requerimento de fulência. Tribunal da Relação de Minas Gerais. Comarca de Muzambinho. Agravo ni. 1.632. Santos Moreira \& Cia. vs. Nicolau Farani. 15 pags. Secção de Obras do $O$ Estado de São Paulo, 1918.

18. Da falência das sociedades irregulares. - Juizo de Direito da 3. ${ }^{a}$ Vara Comercial. Comarca de São Paulo. Processo de falência. Luiz Bertoldo vs. Anselmo Cerello. 20 págs. Oficinas Gráficas da Revista de Comércio e In.dústria. São Paulo, 1918. 
19. Do valor das contas mercantís. - Tribunal de Justiça de São Paulo. Comarca de Serra Negra. Apelação civel n. 9.813. Vaz de Almeida \& Cia. vs. José Liserre. Acórdão de 17 de maio de 1921 (Revista dos Tribunais, de São Paulo, vol. 38, pág. 265). 11 pags. Casa Pindorama. Amparo, 1919.

20. Da prova da verdade nos crimes de calúnia. --. Juizo de Direito d'a 1. ${ }^{\text {a }}$ Vara Criminal. Comarca de São Paulo. O caso dos azeites Brandão Gomes \& Cia. e a Ciàmara Portuguêsa de São Paulo. Manoel de Barros Loureiro e outros vs. Antonio Proença \& Cia. 35 págs. Olegário Ribeiro, Lobato \& Cia., editores. São Paulo, 1919.

21. Um caso de apropriação indébita. - Tribunal de Juistiça de São Paulo. Comarca da Capital. Recurso crime n. 4.020. A Justiça vs. Manuel Jacinto de Araujo. Razões da parte auxiliar Martins Ferreira \& Cia. 20 págs. Olegario Ribeiro, Lobato \& Cia. Ltda., editores. São Paulo, 1919 .

22. Estudos de Direito Comercial. - Editores, Olegário Ribeiro \& Cia. 270 págs. São Paulo, 1919.

Teve esta obra, hoje rarissima, o seguinte prefácio, de J. X. Carvalho de Mendonça:

"Não têm passado despercebidos os recentes estudos sôbre a matéria comercial, apresentados por uma pleiade de jovens, notaveis pelo apuro do trabalho e pela louvável preocupação de manter a tradição do direito nacional.

"Entre os lidadores nessa obra patriótica concorrendo para aperfeiçoar o nosso direito comercial um dos que mais se distinguem é o Dr. Waldemar Ferreira, que reune, agora, neste volume, os seus brilhantes escritos, bastantemente conhecidos e apreciados, sem favor, no nosso meio jurídico. 
"Não se trata de um livro escrito com outros livros, mas de uma obra original, recomendável pelo profundo conhecimento, revelado pelo seu autor, das nossas leis comerciais e dos princípios científicos que as informaram, pelos conceitos assentados com segurança e simplicidade e ainda pela exposição amena, sempre em boa linguagem, das mais intrincadas e difíceis questões teóricas e praticas.

"Os que lerem as monografias do erudito jurista, enfeixadas neste volume, verificarão que nas breves linhas acima não se procurou lisonjear. Mereceriam êsses estudos insígnes que se dissesse muito mais."

23. Os credores privilegiados e o direito de pedir a falência. - Dissertação para concurso ao lugar de professor substituto da sexta secção da Faculdade de Direito de São Paulo: Direito Comercial. Tése oitava da primeira cadeira do quarto ano, parte de Falências, proposta pelo Exmo. Sr. Dr. WRederico Vergueiro Steidel, professor catedrático. - 76 pgs. - Editores, Olegario Ribeiro \& Cia. São Paulo, 1919.

Estampou o Diário Popular, de São Paulo de 3 de março de 1920, estas “impressões de leitura", de Eurico SoDrÉ:

"Concorrendo à regência da cadeira de Direito Comercial na velha Faculdade de São Paulo, apresenta o autor três dissertações: $O$ Menor Comerciante, Os Credores Privilegiados e o Direito de Pedir a Falência e A Hipoteca Naval no Brasil. São trabalhos que revelam uma cultura admirável na idade do autor. Dir-se-iam escritos por velhos Juristas que, despedindo-se da vida, sonhassem deixar num livro lembranças de suas canseiras numa existência votada inteira ao estudo.

"Lecionando Direito Comercial na extinta e perseguida Universidade de São Paulo, firmou Waldemar Ferreira, đefinitivamente, a sua reputação de jurista. Suas aulas atraíam sempre alunos que não eram obrigados à frequência, tanto tinham de valor.

"Assíduo no convívio dos livros e profundo nas suas opiniões pessoais, êsse moço de talento eu vaticino, será o substituto de Carvalio de Mendonga, no prestígio científico entre os nossos comercialistas.

"Quem assim começa. só assim acabará." 
24. O menor comerciante. --- Dissertação para concurso ao lugar de professor substituto da sexta secção da Faculdade de Direito de São Paulo: Direito Comercial. Tése primeira da primeira cadeira do terceiro ano, parte de Direito Comercial Terrestre, proposta pelo exmo. sr. Dr. Gabriel de Rezende, professor catedrático. - 67 págs. Editores, Olegario Ribeiro \& Cia. São Paulo, 1919.

25. A hipotéca naval no Brasil. - Dissertação para concurso ao lugar de professor substituto da sexta secção da Faculdade de Direito de São Paulo: Direito Comercial. Tése primeira da primeira cadeira do quarto ano, parte de Direito Comercial Maritimo, proposta pelo exmo. Sr. Dr. Frederico Vergueiro Steidel, professor catedrático. — 81 págs. - Editores, Olegario Ribeiro \& Cia. São Paulo, 1919.

26. Manual do comerciante. - Editores, Olegario Ribeiro \& Cia. 187 págs. - São Paulo, 1919.

Em sua edição de 21 de fevereiro de 1920 , e na sua secção de - Bibliografia, inseriu O Estado de São Paulo esta notícia:

"A simples enumeração dos trabalhos que nos enviou o Dr. Waldemar Ferreira mostra a operosidade desse jurista. A leitura desses trabalhos adiciona a essa im. pressão a de que não é só a operosidade a qualidade estimável do jovem escritor. Outras possui êle e dos melhores quilates: é claro, é singelo, é erudito e é metódico.

"Os três primeiros estudos são dissertações que o Dr. WALDEMar FerReira apresentou à Faculdade de Direito de São Paulo para o concurso que se realizará proximamente, a fim de ser preenchida a vaga existente de lente de Direito Comercial. $O$ método seguido nas três dissertações é o mesmo. O autor expõe correntiamente a 
matéria de que trata, como se já estivesse falando para os alunos, tendo o cuidado de levantar o menor número possivel de dúvidas e de objeções. A exposição desliza suavemente sem esforço e sem fadiga, de maneira a comunicar a quem a lê uma nítida idéia da matéria tratada.

"O último dos trabalhos do Dr. Waldemar FerReira - o Manual do Comerciante compõe-se de uma abundante série de pareceres que êle teve ocasião de emitir como consultor juridico, que é, da Revista de Comércio $e$ Indústria. Todos êsses pareceres têm uma feição prática muito atraente e recomendam-se, como dizem os editores, pela clareza da exposição e pela segurança do critério que os inspirou.

"O livro é dividido em cinco partes. Na primeira, vêm pareceres relativos a escrituração mercantil, a contabilidade, a livros comerciais, 'à matrícula e ao registro de firma; a segunda é consagrada exclusivamente a questões sôbre sociedades comerciais; a terceira trata de letra de câmbio e nota promissória; a quarta estuda contratos comerciais, cartas missivas, cartas de fiança, contas correntes, compra e venda, comissão mercantil, contrato de transporte, conhecimentos, caixas postais, marcas de fábricas e nome comercial, hipoteca e penhor mercantil e balanços; a quinta, finalmente, refere-se ao imposto de sêlo, a.os de consumo e à liberdade de comércio.

"Este Manual não será de utilidade apenas para os comerciantes, como se inculca. Sê-lo-á igualmente para os próprios advogados, os quais encontrarão nêle solução pronta a muitas dúvidas e alguns ensinamentos de valia".

27. Das Sociedades por Quotas, de responsabilidade limitada. - Um novo tipo de sociedade comercial. - Decreto n. 3.708, de 10 de janeiro de 1919, acompanhado de uma sucinta noção do mecanismo da lei. - E' a quarta edição do trabalho. Escrito para a Revista de Comércio $\boldsymbol{e}$ Industria, que o publicou em primeira edição, vol. II, pags. 1 a 60, teve segunda edição na Revista Juridica, da Livraria Francisco Alves, do Rio de Janeiro, vol. XIV, págs. 25 a 48. A terceira edição saiu nos Estudos de Direito 
Comercial. - 41 págs. - Tip. da Livraria Universal, de Echenique \& Cia., Pelotas.

28. Uma questão de competência. - Juizo de Direito da Comarca de Piracáia. Estado de São Paulo. Recurso de agravo. Santa Casa de Misericordia de Piracaia vs. João Marcolino da Silva. 14 págs. Tip. Sociedade Editora Olegario Ribeiro. São Paulo, 1920.

29. Do depósito como meio de evitar a falência. Tribunal de Justiça de São Paulo. Comarca de Santos. Carmello D’Agostino vs. Pascual Gomez \& Cia. 14 págs. Estabelecimento Tipográfico M. Miglino. - São Paulo, 1920.

30. Uma impugnação de crédito. - Tribunal de Justiça de São Paulo. Comarca da Capital. Agravo n. 11.101. Aluminium Company of South America vs. Cotonificio Rodolfo Crespi. 49 págs. Secção de Obras do O Estado de São Paulo, 1921.

31. Destituição de liquidatário. - Tribunal de Justiça de So Paulo. Comarca da Capital. Agravo n. 11.116. Aluminium Company of South America vs. Massa Palida da Sociedade Importadora de Automóveis. 17 págs. Secção de Obras do O Estado de São Paulo, 1921.

32. Da reivindicação na falência. - Tribunal de Justiça de São Paulo. Comarca da Capital. Agravo n. 11.138. Aluminium Company of South America vs. Ame- 
rico Martins Junior \& Cia. 12 págs. Secção de Obras do O Estado de São Paulo, 1921.

33. Do privilégio dos despachantes. - Tribunal de Justiça de São Paulo. Comarca da Capital. Agravo n. 11.104. Aluminium Company of South America vs. Americo Martins Junior \& Cia. 11 págs. Secção de Obras do O Estado de São Paulo, 1921.

1922

34. Uma questão de agua. - Tribunal de Justiça de São Paulo. Comarca de Jahú. Apelação Cível n. 11. 742. D. Adelia Ferraz Prado vs. Pedro Francischini. 47 págs. Oficinas Gráficas Monteiro Lobato \& Cia. - São Paulo, 1922.

35. Do regime de bens do estrangeiro. - Tribunal de Justiça de São Paulo. Comarca de Jahú. Apelação Cível n. 11.277. Luiz e Guilherme de Pauli vs. D. Minato Maria Stella. 24 págs. São Paulo, 1922.

36. I) a reserva de bens em inventários. - Tribunal de Justiça de São Paulo. Comarca da Capital. Agravo n. 12.307 D. Maria Antonieta Moratti vs. Espolio de D. Violeta de Carvalho. Acórdão na Revista dos Tribunais, de São Paulo, vol. 47, pág. 408. 13 págs. São Paulo, 1923.

37. Arame farpado é "ferragem"? - Tribunal de Justiça de São Paulo. Comarca da Capital. Uma questão de marca de fábrica. Martins Ferreira \& Cia. vs. Antônio Motta \& Cia. Agravos ns. 12.360 e 12.367. Acórdão de 24 de maio de 1923, na Revista dos Tribunais, de São Paulo, vol. 47, pág. 180 a 181. 18 págs. São Paulo, 1923. 
38. Da alegação da perda de titulos em executivo cambiário. - Tribunal de Justiça de São Paulo. Comarca de Campinas. Apelação Civel n. 11.923. Manoel Martins de Araujo vs. Alfredo Aguiar. Acórdãos de 27 de abril de 1923 e 26 de agosto de 1924, na Revista dos Tribunais, de São Paulo, vol. 51, págs. 222 a 225. 23 págs. Tip. Monteiro Lobato \& Cia. - São Paulo, 1923.

39. Um caso de recurso extraordinário. -- Supremo Tribunal Federal. Carta testemunhavel n. 3.612, de São Paulo. Francisco de Paula Sergio vs. José Antonio Capistrano. Acórdão de 3 de outubro de 1923, na Revista do Supremo Tribunal F'ederal, do Rio de Janeiro, vol. 57, pág. 194, e vol. 60, pág. 86. 14 págs. Oficinas Gráficas Monteiro Lobato \& Cia. - São Paulo, 1923.

40. Da imitação de marca de fábrica. - (O "Guaraná Espumante" em fóco). - Junta Comercial de São Paulo. Agravo n. 99. Zanotta, Lorenzi \& Cia. vs. Grande Manufatura Brasileira de Bonbons. 21 págs. Oficinas Gráficas Monteiro Lobato \& Cia. - São Paulo, 1923.

41. A marca "Sanguigenol" e seus imitadores. - Tribunal de Justiça de São Paulo. Comarca da Capital. D. Irma de Godoy Cardoso vs. Augusto Niklaus. Acórdão de 8 de novembro de 1923, na Revista dos Tribunais, de São Paulo, vol. 465 a 467. 14 págs. Oficinas Gráficas Monteiro Lobato \& Cia. São Paulo, 1923.

42. Manual do Comerciante. - Segunda edição revista muito aumentada. - 328 págs. - Editores, Monteiro Lobato \& Comp. — São Paulo, 1923.

Na Revista Argentina de Ciências Politicas, de Buenos Aires, Ano XIII, tomo XXVI, de 1923, pág. 539, escreveu o Professor Dr. Mario A. Rrvarola, seu diretor, esta apreciação bibliográfica: 
"Ha aparecido la segunda edición de esta obra, interesante para un conocimiento de conjunto de las disposiciones legales relativas a los comerciantes. Sus primeros capitulos se encuentran dedicados a la contabildiad en general y al modo especial propio ide algunos géneros de comerció. Se ocupa luego de la matrícula, y pasa en seguida a tratar las sociedades comerciales bajo sus distintos aspectos y según el negocio a que se dedican. Luego se ocupa de las sociedades anónimas y por acciones, cooperativas y sociedades extranjeras de seguros, para tratar en seguida la letra de cambio y los pagarés. A continuación se exponen los diversos contratos comunes de comercio, enajenación de la hacienda comercial, marca de fábrica.

"Son objeto de exposición tambén el concordato, la falencia, la hipoteca y la prenda mercantil, y mas adelante los seguros y la cuenta corriente bancaria. La última parte del libro está destinada al transporte, navegación $\mathbf{y}$ averias, para terminar con la materia relativa a los impuestos de exportación, impuestos estaduales e interestaduales y de consumo".

43. Dos emprestimos municipais mediante letras de câmbio. - Tribunal de Justiça de São Paulo. Comarca de Dois Corregos. Embargos n. 11.925. Antonio Zuardi vs. Câmara Municipal de Mineiros. Oficinas Gráficas Monteiro Lobato \& Cia. 39 págs. São Paulo, 1923.

44. O chocolate "Lacta" e os imitadores de sua etiqueta "Andorinha". - (Uma questão de marca de fábrica) Tribunal de Justiça de São Paulo. Comarca da Capital. Recurso crime n. 4.850. Francisco Pistone vs. Zanotta, Lorenzi \& Cia. Acórdão de 7 de agosto de 1925, na Revista dos Tribünaišs, de São Paulo, vol. 51, pág. 92 a 97. 41 págs. Tip. Rossetti \& Rocco. São Paulo, 1924. 
45. Um caso de fraude contra credores. - Tribuna] de Justiça de São Paulo. Comarca de Barretos. Apelação civel n. 13.087. José Perereira Novo vs. Serafim Jorge Ferreira. 29 págs. Oficinas Gráficas Monteiro Lobato \& Cia. - São Paulo, 1924.

46. O Novo regulamento da Propriedade Industrial. - (Uma campanha da Associação Comercial de São Paulo). - Tribunal de Justiça de São Paulo. Comarca da Capital. Agravo n. 13.268. Baruel \& Cia. vs. Junta Comercial de São Paulo. 50 págs. Tip. Rossetti \& Rossi. - São Paulo, 1924.

A proposito dêste volume escreveu J. X. Carvalho de Mendonça:

"Tenho recebido sempre e lido com aproveitamento e prazer os seus trabalhos forenses. Ainda agora, tenho diante de mim cinco belos bolhetos, trabalhos admiráveis de impressão e magníficos no interior. $O$ novo regulamento da Propriedade Industrial (min. ag. n. 13.268) é digno de apreciação. Que belo estilo! Quanto conceito justo, ainda que meio pejorativo...

"Todos os seus trabalhos primam pela bela exposição. A isso é que chamo escrever bem português".

47. Do nome comercial como marca de fábrica. Tribunal de Justiça de São Paulo. Comarca da Capital. Sotto Mayor \& Coletes vs. Sotto Maior \& Cia. 13 págs. Tip. Rossetti \& Rocco. — São Paulo, 1924.

48. Em prol de uma instituição de caridade. - Tribunal de Justiça de São Paulo. Embargos n. 11.855. Comarca de Caçapava. Dr. João Evangelista Rodrigues vs. Conferência de São José. 39 págs. Tip. Rossetti \& Rossi. - São Paulo, 1924.

\section{5}

49. Liquidação de sociedade. - Tribunal de Justiça de São Paulo. Comarca da Capital. Agravo n. 14. 159. Armin- 
do Machado Leite vs. Erwin Hafstetter e Julio D'Eça. 20 págs. Casa Rosenhain. - São Paulo, 1925.

50. Sociedades por Quotas. - Quinta edição revista e aumentada. - 352 págs. - Companhia Gráfico-Editora Monteiro Lobato. - São Paulo, 1925.

E da Revista de Jurisprudencia Argentina, de Buenos Aires, ano 17, fasciculo n. 16, de maio de 1934, esta nota, da lavra de JuAn Justo DASSEN :

"Obra de un comercialista de nota, el libro que nos ocupa constituye una estimada contribuición al estudio de las sociedades de responsabilidad limitada.

"Se investigan en ella con elevado espíritu crítico y loable minuciosidad, los numerosos problemas juridicos y prácticos que tales sociedades suscitan. Estas dificultades derivan, en parte, de la naturaleza poco definida de esos entes, que participan de los caracteres de las sociedades colectivas y de las anónimas.

"Comienza el trabajo con una interessante nota histórica en la que se hace referencia a las legislaciones de Inglaterra, Alemanha, Portugal, Austria, Suiza e Italia, sobre la materia, indicando, em forma sintética, pero clara, sus características. Señala las ventajas que tal forma de sociedades representa para las empresas modestas; expone la opinión adversa de MARghiERI, y la favorable de la comisión presidida por Vivante y compuesta por los mas eminentes juristas y professores de Italia que proyectaron el nuevo código de comercio presentado al gobierno en el año 1922.

"En lo que respeta a la legislación comercial brasileña, hace notar que la misma no se ocupó de las sociedades de responsabilidad limitada hasta el decreto núm. 3708, de enero 10 de 1919, que las reguló. Se ocupa de los antecedentes patrios de este decreto, manifestando que ya en el año 1865 el consejero Nabuco dE ARAujo había formulado um proyecto regulamentando esas sociedades a semejanza de las que existian en Inglaterra y en Francia. El 20 de septiembre de 1918 el diputado por el estado de Rio Grande do Sul, doctor Joaquim Luiz Osorio, presentó 
a la cámara de que formava parte un proyecto de sociedades de responsabilidade limitada, calcado sobre el contenido en el proyecto de código de comercio - cuya consideración por el senado recién se iniciaba - de que es autor el notable jurisconsulto brasileño doctor INGLEZ DE SouzA. Con el dictamen favorable de las respectivas comisiones de justicia y negocios constitucionales de ambas cámaras legislativas el proyecto quedó convertido en ley, casi sin discusión, por decreto núm. 3708, de enero 10 de 1919.

"Hace notar el autor que debido a la inexplicable precipitación con que dicho proyecto fué sacionado no pudo ser debidamente estudiado y discutido. De ahí las diferencias y lagunas que ofrece la ley, las que, según prevê, serán un tormento para el comercio y para los tribunales que la apliquen.

"A esa noticia histórica sigue un concienzudo estudio de la estructura de las sociedades por cuotas, de los requisítos del contrato social, del objecto de la sociedad, de la firma o denominación social, del uso de estas, de las facultades y responsabilidad de los socios gerentes, del capital social, de las cuotas, de los socios o cuotistas, de la admnistración social, de la emisión de obligaciones al portador, de la transformación de sociedades de otros tipos en sociedades por cuotas, de la fusión e incorporación de sociedades de distintos tipos, del concordato preventilvo, de la quiebra, de la liquidación, del impuesto sobre la renta. Además, se insere un apéndice conteniendo las opiniones sobre el proyecto de NABUco DE Araujo, emitịdas por la Associação Comercial e Beneficente de Pernambuco, Tribunal do Comércio da Côrte, y del Instituto dos Advogados Brasileiros.

"Cierra el libro un útil indice alfabético de materias.

"Es digna de mencionarse la amplia y selecta información de doctrina y de jurisprudencia judicial y administrativa que acusa la obra comentada."

51. As terras do Ribeirão Doce. - Ação de reivindicação das terras do Ribeirão Doce e Batalha. - Juizo Federal da Secção de São Paulo. - 1. a Vara. - D. Maria de Mi- 
randa Castro vs. Orosimbo Morais Navarro. - 50 págs. São Paulo Editora Limitada. - São Paulo, 1926

52. Apelação civel n. 5.593 - Supremo Tribunal Federal. A Companhia Nacional de Estamparia vs. União Federal. 55 págs. Oficinas de Obras d'O Globo. -- Rio de Janeiro.

53. Da autorização judicial para vendas de massas falidas. - Tribunal de Justiça de São Paulo. Comarca da Capital. Agravo n. 15.114. Hugo Charles Braun vs. Massa Falida da S. A. Tecelagem Taubaté. 23 págs. - São Paulo Editora Limitada. - São Paulo, 1927.

54. Da responsabilidade civil da massa falida por culpa dos seus representantes. - Dissertação para o concurso à cadeira de Direito Comercial da Faculdade de Direito de São Paulo. — 70 págs. - São Paulo Editora Ltdā, 1927.

I. Da secção - Livros novos de Rodrigues DE Carvalho, no Correio da Manhã, da Paraíba, de 9 de outubro de 1928:

"Trata-se de uma tése inédita, esta de vincular-se a massa falida pelos atos danosos contra terceiros praticados pelos sindicos ou liquidatários.

"O trabalho é bem metodizado, fundido nos moldes do direito civil, à luz da legișlação comercial e da doutrina.

“É de oportunidade a matéria estudada, agora que se tem em formação no Congresso o Código Comercial projetado pelo saudoso INGLEz DE SouzA".

II. "L'A sostiene che, a norma del diritto locale dello Stato di San Paolo, la massa fallimentare non risponde civilmente per la colpa di suoi rappresentanti, e questo perche non é persona giuridica di diritto privato e pertanto é incapáce di acquistare diritti e di assumere obbligazioni per- 
che la legge sui fallimenti esclude dalla ripartizione delle passivitá della massa le obligazioni risultante da atti illiciti compiuti dal sindico o dai liquidatori"

La Giustizia Penale, de Roma, ano XLII (1936) fasc. 1.

III. "El A. llega a las seguientes conclusiones: La masa no responde por culpa de sus representantes. No responde porque: $I$, no es persona juridica de derechos y contraer obligaciones; II, la ley de quiebras excluyó de las deudas de la masa las obligaciones resultantes de actos ilícitos praticados por los síndicos y liquidadores.

"Para llegar a esas afirmaciones, se desarrollan principalmente los problemas atinentes a la administración de la quiebra, el nombramiento y posición juridica de los síndicos y liquidadores dentro de la misma, los principios de la responsabilidad por acto propio y por actos de terceros; la responsabilidad civil directa e indirecta de las personas jurídicas y impersonalidad jurídica de la masa falida"...

(Boletin Bibliográfico de la Facultad de Derecho y Ciencias Sociales, de Montevideo, n. 3, de 1935).

55. Sociedades comerciais irregulares. - Dissertação para concurso à cadeira de Direito Comercial da Faculdade de Direito de São Paulo. — 173 págs. — São Paulo Editora Limitada, 1927.

I. Da secção - Livros novos, de RoDRIGUes DE CARvalho, no Correio da Manhã, da Paraiba, de 9 de outubro de 1928:

"Do notavel comercialista sociologo que é o Dr. Waldemar Ferreira, de São Paulo:

Socidades comerciais irregulares, 1927. - S. Paulo Editora. 170 paginas in folio.

"O provecto jurista sobre ser um insigne advogado, dedica-se a escrever monografias referentes a materias do direito comercial ainda não estudadas devidamente.

"No comércio brasileiro é uso frequente não se legalizarem as sociedades, que funcionam como personalidades de fato e não de direito.

"Graves são os prejuizos decorrentes, e perigosas são as lacunas consequentes. Pelo nosso regime são essas sociedades declaradas falidas com todos os onus contra os 
respectivos sócios, ao passo que êstes não têm em seu favor as regalias conferidas pela lei a.os socios das sociedades regulares".

56. Curso de Direito Comercial. - Tipografia Siqueira. Salles Oliveira, Rocha \& C. - São Paulo, 1927.

Volume primeiro. - Parte geral. Do comerciante e seus auxiliares. Preleções feitas na Faculdade de Direito de São Paulo no ano letivo de 1925. Primeira cadeira do terceiro ano. - 323 págs.

Volume segundo. - Da falência e da concordata preventiva. Preleções feitas na Faculdade de Direito de São Paulo no ano letivo de 1926. Primeira cadeira do quarto ano. - 392 págs.

Da secção bibliográfica de Plinio Barreto no $O$ Estado de São Paulo, de 23 de julho de 1927:

"O concurso, apesar de todos os defeitos que tem, e não são poucos, continua a ser o processo mais aceitavel para a escolha de candidatos a cargos técnicos. Se lhe adicionassem, antes ou depois de realizado, um periodo de exercicios práticos chegariamos quáse là perfeição. Por si só, póde êle revelar no candidato algumas virtudes apreciáveis, como a agilidade de expressão, o dominio dos nervos e a faculdade Ide assimilação. Mas, raramente revelará o principal, que é conjunto de tudo isso e mais um "que" indefinido, istó é, o talento especifico para a função que o individuo pretende exercer. 0 professor, por exemplo, não bastará que se recomende pelos dotes de eloquência ou pela extensão do saber. Requer mais alguma coisa, que é aquilo que se poderia chamar o talento didático, o jeito especial de expôr sem ficar aquém e sem ir além da capacidade de compreensão do aluno, mantendo-lhe sempre alerta, vivaz e interessada, a atenção inexperiente. Isso, essa qualidade primordial não se apura nos concursos, ou raro se apurará. Só se mostra no exercicio do ensino.

"Para o juiz não será suficiente, também, a denúncia de inteligência e preparo. Faz-se mistér ainda o concurso da prática forense. Ponha-se um rapaz de genio a julgar cau- 
sas sem experiência do oficio e não terão conta os erros em que incidirá.

“Não se devia, penso eu, confiar uma cadeira de professor e revestir da toga ao magistrado a quem, ao saber comum, bebido nos livros, não possa adicionar ainda o saber de experiências feito. Professores e juizes não há quem os tolere principiantes e bisonhos.

"Não se distanciam idas minhas as idéias que a êsse respeito nutre o sr. WALDEMAR FERREIRA. Na preleção inaugural do Curso de Direito Comercial, que na qualidade de livre docente, realizou na Faculdade de Direito desta capital, durante a ausência do catedrático, sustentou s. s. também que para ensinar não basta saber. "É necessário o condão misterioso que põe em vibração os espiritos para que entre êles se opere a transfusão dos conhecimentos.

“Creio que êsse condão, despertado pelo hábito de ensinar nessa interinidade proveitosa, descobriu o jovem professor. O seu Curso de Direito Comercial, que, aliás, não saiu completo, conquanto fosse bem desenivolvido e, talvez por isso mesmo, demonstra que o professor está amadurecido para o delicado oficio. Quando vier a reger definitivamente a cadeira, que disputa, já não atormenterá os alunos. As suas preleções são claras, precisas e metódicas. Estão ao alcance das inteligências médias e acredito que ao alcance também das que se põem abaixo das médias. Ao distinto livre docente não falta siquer uma das qualidades essenciais mas pouco encontradiças, que é a coragem das opiniões.

“Gostei de về-lo, na preleção inaugural, cair em cheio sôbre os advogados e juizes que, no Brasil, como em toda a parte, armam escandalo com a sua carência de convicções jurúdicas. "A carência de convicções, ou jurídicas ou econômk cas ou financeiras, notadamente a ausência de convicções políticas, eis o grande mal brasileiro. Vivemos ao Deus dará, num empirismo espantoso, fazendo experiências arriscadas, mas cortando com elas o cerne da nacionalidade". Não há, com efeito, tristeza maior para os espiritos sérios do que a volubilidade dos nossos juristas. Poucos são, desgraçadamente, os advogados capazes de subordinar os interêsses da advocacia à disciplina dos principios jurídicos. A maioria não se envergonha de escravizar êsses principios àqueles interêsses. Torcem-nos ou os abandonam ao sabor da necessidade da hora e da conveniência do momento. Na politica, 
então já se tornou coisa corriqueira o desprezo das convicções juridicas. Ninguem se embaraça com elas: ninguem lhes dá a minima atenção. O que reina, ali, é o sofisma, e o sofisma lé o inimigo figadal da conviøção.

"Além do Curso de Direito Comercial, o sr. Waldemar Ferreira publicou, reecentemente, duas teses: Da responsabilidadie civil da massa falida por culpa dos seus representantes e Sociedades Comerciais Irregulares.

“Ambas são interessantes. Não me é possivel, evidentemente, analisá-las com minúcia. Não posso, entretanto, deixar passar sem reparo a doutrina de que os credores poderão ser responsáveis, em certas hipóteses, pelos atos dos liquidatário das massas falidas. Os liquidatários, argumenta o sr. Waldemar Ferreira, são mandatários dos credores, pois são êstes que os elegem em assembléia. "Se no exericicio de suas funções atos perpetrarem, violando o direito ou causando prejuizos a outrem, culposa ou dolosamente, mas atos que caibam nas atribuições de seu cargo, por êle responderão os mandantes, os representados — os credores, se se fizer tambiém a prova de sua culpa ou negligência".

“Confesso que não posso concordar com essa tese. Os liquidatarios não são apenas simples mandatários dos credores. Eles e os sindicos, como bem o observa o sr.Carvalmo DE MENdonç, são órgãos da massa dos credores na sua unidade. Não existem só para beneficio dos credores. "São instituidos no interêsse público para a realização do escopo da falência, derivando-se diretamente da lei o título do exercício das funções que lhes são confiadas.

"E exato que são eleitos pelos credores e que pelos credores podem ser destituidos. Mas também o é que permanecem no cargo e atuam sob a direço e superintendência dos juizes. "Em virtude desse grande poder de natureza administrativa confiada ao juiz - o ensinamento ainda é do sr. Carvalho de Mendonça - êste tem ainda a faculdade de ex-oficio, ou a requerimento dos interessados, ou do representante do Ministério 'Público, que é fiscal da execução da lei, solicitar daqueles órgãos da massa falida - (os sindicos e liquidatários) quaisquer informações úteis, exigirlhes conta da gestão, chamar-lhes ao cumprimento dos deveres legais, impedir atos contrarios da lei, usando, se necessário fôr, do meio extremo da destituição". 
"Esta lição é simples desenvolvimento do que está expresso no art. 69 da lei de falências. Se o liquidatário é um orgão da massa dos credores e exerce funções do interêsse público, os atos, que pratica, dentro das atribuições legais, só podem vincular, quando lesivos de direitos de terceiros, a massa, de que é órgão, e não os credores, que a constituem, assim como os atos análogos, praticados por um dos órgãos da administração de uma sociedade anônima só vinculam a responsabilidade da sociedade e não a dos acionistas.

"O sr. Waldemar Ferreira tenta prender os credores ao liqüidatário pelo gancho da culpa in vigilando. Ficam responsaveis pelos atos dêste, porque, diz, devem acompanhar de perto a administração do liquidatário, fiscalizando-lhe os atos. Se verificarem que êle anda mal e não o destituem incidirão na culpa in vigilando.

"Nesse caso, deveria s. s. também forjar cadeias iguais para o Estado, quando o juiz, diretor e superintendente do liquidatário, o veja proceder mal e não o destitua ex-officio...

“Ou a responsabilidade será exclusivamente dos liqüidatários ou, ento, será dles e da massa. Dêles e dos credores é que não pode ser. E não pode ser por isto: a lei de falências estabelece a responsabilidade dos liquidatários somente para com a massa falída. Não cogita da sua responsabilidade para com os credores, pessoalmente. Quer isto dizer que, na economia da lei, tudo quanto o liquidatário fizer no exercicio de suas funções repercutirá no patrimônio da massa, mas não irá, por cima dêsse patrimônio, atingir aos credores individualmente. Direitos e deveres êle os tem unicamente em relação à massa. Perante a massa responde êle pelo abuso que praticar. Pelo abuso, pela má fé, pela infração da lei, pela má administração, pela desidia e pela negligência. 0 abuso póde consistir num ato ilicito. Se êle responde à massa pelos abusos é manifestamente pörque, em consequência dêsses abusos se geraram para a massa danos e prejuizos injustos. O parágrafo 1.0 do art. 72 da lei torna bem visivel que os laços de solidariedade amarram o liquidatário $\mathrm{e}$ a massa $\mathrm{e}$ nằo $\mathrm{o}$ liquidatário e os credores: Seria uma coisa contrária a todos os principios jurídicos que os credores respondessem indivi- 
dualmente pelos atos do liquidatário e só a massa é que tivesse contra êle, como só ela é que tem, ação para se cobrir dos danos e prejuizos que os seus atos causarem.

"Provavelmente, nenhum de nós tem razão, ou temo-la ambos. Em controversias juridicias, sobretudo em torno dos textos legais, é mais fácil que todos tenham razão do que alguém deixe de tê-la".

57. Desfazendo razões de máu pagador. - Tribunal de Justiça de São Paulo. Comarca de Salto Grande. Eduardo Salgueiro vs. Barros \& Cia. 24 págs. São Paulo Editora Limitada, 1928

58. A Congregação da Faculdade de Direito de São Paulo na Centúria de 1827 a 192\%. - Separata da Revista da Faculdade de Direito de São Paulo, vol. XXIV, - Tipografia Siqueira. - 185 págs. - São Paulo, 1928.

\section{9}

59. Manual do Comerciante. - Terceira edição. 404 págs. - Companhia Editora Nacional. - São Paulo, 1929.

Escreveu Juan Justo Dassen na Revista de Jurisprudência Argentina, de Buenos Aires, ano 17, n. 16, de maio de 1934:

“Este libro está constituido por la reunión de 213 consultas juridicas sobre toda suerte de asuntos comeroiales, evacuadas por el jefe del consultorio juridico del Centro do Comércio e Indústria de São Paulo, doctor Waldemar Martins Ferreira.

"Las opiniones vertidas por este ilustre jurista íbanse publicando en la Revista do Comércio e Indústria, órgano de publicidad de esa associación de comerciantes, hasta que en el año 1919 los editores resolvieron reunirlas en un volumen que denominaron Manial do Comerciante. 
"La alta autoridade del autor como comercialista y el fin eminente práctico de su obra hicieron que las dos primeras ediciones de ésta se agotasen rápidamente no obstante su gran tirada.

"Un minucioso indice alfabético de la materia facilita notablemente la consulta de este libro."

60. Defendendo um crédito hipotecário. - Tribunal de Justiça de São Paulo. Segunda Câmara Civil. Comarca de São José dos Campos. Apelação civel n. 16.684. José Ricardo Leite vs. Antonio Fernandes Cruz. 46 págs. Empresa Gráficaı Ltda. — São Paulo, 1929.

61. Por uma suposta apropriação de três centimetros de terreno. - Tribunal de Justiça de São Paulo. Terceira Câmara. Comarca da Capital. Apelação civel n. 16.858. J. A. Nascimento Gonçalves vs. Dr. Paulo Nacarato. 41 págs. — São Paulo Editora Limitadia, 1929.

62. A propósito de remuneração de mandatários. Tribunal de Justiça de São Paulo. Segunda Câmara. Comarca da Capital. Apelação Civel n. 17.397. Associação Comercial de São Paulo vs. Ateliers de Constructions Electriques de Charleroi. 34 págs. - São Paulo Editora Limitada, 1929.

63. Do direito do interessado à sua remuneração. Tribunal de Justiça de São Paulo. Terceira Câmara. Comarca da Capital. Apelação civel n. 17.222. Eliseu Zucchi vs. Luiz Blumenthal. 59 págs. - São Paulo Editora Ltda., 1929.

64. Questões de Direito Comercial. - Pareceres. Primeira série. - Tipografia Siqueira. Salles Oliveira, Rocha \& Cia. - 426 págs. - São Paulo, 1930. 
I. A propósito dêste livro, J. X. CAarvalho de MendonGA conceituou:

"Tenho na minha frente o volume das - Questões de Direito Comercial, coleção de esplendidos pareceres do eminente colega e mui distinto amigo.

"Somente quem iconhece o nosso meio poiderá bem avaliar a soma de estudo e de outros esforços para se conseguir uma orientação segura na solução dos casos práticos, dificeis e intrincados.

"O seu trabalho é rum manancial de lições fecundas e revela a alta capacidade jurídica do mestre.

"Escusado ı́ dizer que já conhecia a maior parte daqueles pareceres. A muitos me referi no Tratado".

II. Também assim Levi Carneiro se manifestou:

"Agora mesmo, e por êsse motivo, é que pude apreciar uma parte daquela sua gentileza, Jendo as Questões de Direito Comercial e os memoriais que as acompanharam. Sinto que me falte autoridade para o louvôr merecido. Posso, no entanto, dizer-lhe que muito aproveitei nessa leitura e que volverei a essas páginas sempre que tiver de enfrentar qualquer dos assuntos versados nelas com admiravel mestría.

“A sua autoridade está firmada tão seguramente que já não é arriscado prognosticar-lhe a sucessão da de Carvalho de Mendonça. E deje ser um consolo saber que subsistirá o inestimavel contrôle doutrinário e moral das relações comerciais, que o grande MENDonça soube criar entre nós".

65. A responsabilidade por acidente no transporte gracioso de automovel. - Tribunal de Justiça de São Paulo. Terceira Câmara. Comarca da Capital. Apelação civel n. 17.538. Tomaz Vieira dos Santos vs. José Augusto do Nascimento Gonçalves. 67 págs. - São Paulo Editora Limitada, 1930.

66. Rejeição de empreitada. O fracasso dos carneiros hidráulicos "Jordão". - Tribunal de Justiça de São 
Paulo. Tenceira Câmara. Comarca da Capital. Apelação civel n. 17.451. Sociedade Anônima Usina .Esther vs. Dr. Alfredo Jordão Junior. - 69 págs. - São Paulo Editora Limitada, 1930.

67. A conferência de bens do sócio e a sociedade leonina. - Tribunal de Justiça de São Paulo. Terceira Câmara. Comarca da Capital. Apelação civel n. 17.608. D. Leonor de Azevedo Oliveira vs. Dr. Luiz Gonçalves da Silva. -_ 86 págs. - São Paulo Editora Limitada, 1930.

68. A concordata terminativa de falência anterior $\dot{a}$ lei nova e a sua sujeição ao regime desta. - Tribunal de Justiça de São Paulo. Primeira Câmara da Capital. Agravo n. 16.659. Coronel Antonio Gordinho Filho vs. Antenor Vilaça. - 40 págs. — São Paulo Editora Limitada, 1930.

69. A nova lei de falências e a sua elaboração. -Publicação da Associação Comercial de São Paulo. - 136 págs. - São Paulo Editora Limitada, 1930.

\section{1}

70. A propósito de um chéque. - Tribunal de Justiça de São Paulo. Comarca da Capital. Apelação civel n. 18.133. Fabio da Veiga Oliveira vs. Dr. Pelagio Teixeira Marques. -- 41 págs. - São Paulo Editora Limitada, 1931.

71. O endosso pignoraticio de conhecimentos ferroviários. - Tribunal de Justiça de São Paulo. Quarta Câmara. Comarca de Santos. Agravo n. 18.303. Banco do Estado de São Paulo vs. Oliveïros Dias Pinheiro. - 14 págs. São Paulo Editora Limitada, 1931.

72. A caução de conhecimentos por comissários de café. - Tribunal de Justiça de São Paulo. Quarta Câma- 
ra. Comarca de Santos. Agravo n. 18.307. Aristides Dias Pinheiro vs. Banco do Estado de São Paulo. — 12 págs. - São Paulo Editora Limitada, 1931.

73. O requerimento doloso de falência e a obrigação de indenizar. - Tribunal de Justiça de São Paulo. Terceira Câmara. Comarca da Capital. Entreposto Paulista Limitada vs. Silva \& Pinto. - 30 págs. — São Paulo Editora Limitada, 1931.

74. As modificações da firma social e a subsistência da personalidade jurídica. - Tribunal de Justiça de São Paulo. Quinta Câmara. Comarca da Capital. Embargos n. 17.097. Zanotta, Lorenzi \& Cia. vs. Pistone, Wecke \& Cia. - 22 págs. - São Paulo Editora Limitada, 1931.

75. As sesmarias e as terras devolutas. - Tribunal de Justiça de São Paulo. Quinta Câmara. Comarca da Capital. Apelação civel n. 18.155. Dr. José Vicente de Azevedo vs. Companhia Brasileira de Imóveis e Construções. — 61 págs. — São Paulo Editora Limitáda, 1931.

76. A suspensão dos embarques de café e os contratos de compra e venda. - Tribunal de Justiça de São Paulo. Segunda Câmara. Comarca da Capital. Apelação civel n. 19.227. Zerrenner, Bülow \& Cia. vs. Coronel Cândido Pereira Lima. - 31 págs. - São Paulo Editora Limitada, 1931.

77. Um caso de procuração "em causa propria". Tribunal de Justiça de São Paulo. Quinta Câmara. Comarca de Santos. Apelação civel n. 19.342. Miguel A. Rinaldi vs. Otavio Pereira Guimarães. - 54 págs. — São Paulo Editora Limitada.

78. O comércio maritimo e o navio. - Separata da Revista da Faculdade de Direito de São Paulo, vol. XXVI, 
de 1930. 335 págs. - Emprêsa Gráfica da Revista dos Tribunais. - São Paulo, 1931.

1932

79. Da responsabilidade do sócio comanditário. Tribunal de Justiça de São Paulo. Comarca de Santos. Embargos n. 19.342. - Miguel A. Rinaldi vs. Otávio Pereira Guimarães. 149 págs. - Émprêsa Gráfica da Revistu dos Tribunais. São Paulo, 1932.

80. Questões de Direito Comercial. - Pareceres. Segunda série. - 342 págs. - Tipografia Siqueira. Sales Oliveira, Rocha \& Cia. - São Paulo, 1932.

81. O conhecimento do transporte ferroviário. - Separata da Revista da Faculdade de Direito de São Paulo, vol. XXVII. - 179 págs, - Emprêsa Gráfica da Revista dos Tribunais. - São Paulo, 1932.

1933

82. Discursos. - Contém o volume tres orações, duas pronunciadas durante a revolução constitucionalista de 1932 e outra como paraninfo - Palavras do exilio, escritas em Lisboa, aos bacharelandos de 1932 da Faculdade de Direito de São Paulo. - 32 págs. — São Paulo, 1933.

83. As Directrizes do Direito Mercantil Brasileiro. Conferências realizadas na sala dos Atos Grandes da Faculdade de Direito da Universidade de Lisboa, nos dias 7. 11, 14, 17 e 21 de março de 1933. — 247 págs. Tipografia da Emprêsa do Anuário Comercial. - Lisboa, 1933.

Eis o sumário das conferências :

I. A formação. - A partida de D. Joño VI para o Brasil. A carta régia de 28 de janeiro de 1808 e a abertura 
dos pòrtos brasileiros ao comércio internacional. $\mathbf{O}$ Tribunal da Real Junta do Comércio, Indústria, Navegação e Fábricas e as primeiras linhas do código do comércio. A influência de José da Silva LisboA. A faina legislativa e os seus resultados. A lei n. 556, de 25 de julho de 1850 . Os regulamentos comerciais. O papel de José Clemente Pereira.

II. O regime das sociedades mercantis. - o lançamento dos primeiros trilhos ferroviários. As medidas governamentais para o seu desenvolvimento e irradiação. 0 dinamismo de Irineu Evangelista de Souza e a aplicação de capitais estrangeiros no Brasil. A constituição das grandes emprêsas de transportes. A deficiência dos dispositivos do código comercial sôbre as sociedades anônimas e a legislação sôbre elas. As sociedades por quotas de responsabilidade limitada. Os novos problemas das sociedades anônimas e a legislação sôbre elas. As socicdades por quotas de responsbailidade limitada. Os novos problemas das sociedades anônimas e seu encaminhamento doutrinário e legislativo.

III. O surto industrial e mercantil e o seu aparelhamento legislativo. - $\mathrm{O}$ desenvolvimento da industria fabril. A legislação sôbre as marcảs de fábricas e de comércio. As patentes de invenção. A abolição da escravatura e a intensificação da cultura do café, a coluna mestra da economia brasileira. O comércio comissário da praça de Santos e os seus usos e costumes. A intervenção oficial no comércio cafeeiro e os seus institutos de irradiação e de defêsa. Os armazéns gerais. A Bolsa Oficial do Café. Os novos títulos de crédito e a sua legislação.

IV $O$ instituto falimentar. - A proclamação da República e a sua fecundidade legislativa. A refórma do instituto da falência e a abertura de novos horizontes ao direito comercial brasileiro. A influência de CiARLas DE Carvalho e o inlício da obra sistematizadora e monumental de José Xavier Carvalho de Mendonça. Os novos rumos do direito falimentar brasileiro.

V As novas tendências. - A inquietação universal do após guerra e a sua reflexão sôbre as concepções jurídicas. As novas doutrinas do Estado e a sua influência sôbre o direito privado. O sindicalismo contemporâneo e 
a sua irradiação no Brasil. As leis do trabalho ma indústria e no comércio. Os primeiros prenúncios do direito corporativo comercial.

- Discursando, em 23 de maio de 1935, na Academia Brasileira, referiu-se Felix Pacheco a êste livro:

"Regressando há pouco tempo de Poços de CaIdas, tive ensejo de visitar, na Capital Paulista, em companhia do nosso querido colega Afonso TAUNAY, as novas instalações da Biblioteca da Faculdade de Direito, na parte posterior, já reconstruida do velho e tradicional edificio por onde transitaram gerações e gerações de estudantes.

“Coube-me a fortuna de ser apresentado nessa ocasião ao Dr. Waldemar Ferreira, cujo nome é hoje um dos mais belos florões do patrimônio intelectual daquele formidavel pedaço do Brasil, onde o melhor do nosso progresso e da nossa fortuna se vem afirmando todos os dias do modo mais decisivo e mais brilhante.

"Se a politica em nosso país, chegar a ser um dia aquilo que deve ser, isto é, ùma contínua renovação de valores, a gente moça do São Paulo de hoje poderá proclamar com razão que teve a prioridade dêsse movimento de imprescindivel substituição dos homens, abrindo caminho com elevação e patriotismo, sem menosprezar o passado, nem querer de modo nenhum diminuir o porte das velhas figuras que se notabilizaram pelo saber e pelo devotamento à causa pública.

"Combatendo o bom combate pela restauração da ordem juridica contra o prolongamento do regime discricionário, o Dr. Waldemar Ferreira teve de amargar no exilio a virilidade de sua atitude de patriota e homem da lei.

"Mas o exilio, quanāo é a consciência do dever cumprido, não se estiola em negações e ressentimentos, ao contrario floresce ainda mais em trabalhos que continuem ilustrando lá fóra o nome da Pátria distante e sempre amada.

"José BonIFÁcro, literariamente falando-se, foi talvez maior em Bordeaux do que no Rio de Janeiro ou em São Paulo, religando ali o vate ao sábio, que já o era e de renome na Europa inteira antes da Independência, e achando afinal vagares para pôr em ordem os versos antigos de Américo Elysio e escrever novas poesias que 
haviam mais tarde de autorizar-nos sobejamente a inclui-lo na lista dos patronos das cadeiras de nosso sócios correspondentes.

"Do Dr. Waldemar Ferreira se póde dizer sem farvor que seguiu êsse alto exemplo realizando, no seu ócio forçado de Lisboa, uma série de conferências primorosas que souberam dar ao auditório selectissimo da metropole lusitana ideia exata da formação do nosso direito mercantil.

"O suculento tomo em que as aludidas conferências foram depois reunidas faz honra à nossa Brasiliana nêsse ramo particular da ciência jurídica, com o traçado dos seus rumos históricos próprios através dos tempos e dos acontecimentos.

"Portugal teve assim um ótimo ensejo de verificar o preparo intelectual dos nossos homens públicos, cumulando com justiça o Dr. WaLdemar Ferreira das maiores distinções que um intelectual possa aspirar nos centros universitários do Exterior".

\section{4}

84. Tratado de Direito Mercantil Brasileiro. - Volume primeiro: Parte geral. — 490 págs. - São Paulo Editora Limitada, 1934.

Este é o seu prefácio:

"Só por insinceridade poderia eu dissimular as origens e os fins universitários desta obra.

"Esgotados os dois volúmes do meu Curso de Direito Comercial, editados em 1927, não me foi possivel resistir, por mais tempo, às reclamações de meus discipulos. Queriam eles obter exemplares daquele compêndio cada dia mais raros. ensino.

"Tratei de revê-lo para adaptá-lo ao meu programa de

“Estavam já muitas páginas revistas quando a politica me envolveu, dando-me as responsabilidades de uma pasta governamental e, como remate da relvolução constitucionalista de São Paulo, em 1932, o exilio. Desterrado em Portugal, vi-me desde logo cercado pelas atenções dos 
eximios professores da Faculdade de Direito de Lisboa. Acolhido por êles fraternalmente não pude forrar-me da incumbêência, que êles me impuseram, por via de convite gentilissimo, de fazer série de conferências sôbre o direito brasileiro naquele notavel instituto de ensino superior.

"Quando tive a honra de iniciar na sala dos Atos Grandes da Faculdade de Direito de Lisboa, o meu curso, reproduzido em volúme - As Directrizes do Direito Mercantil Brasileiro, o professor ABEL DE ANDRAde no discurso, com que se dignou de apresentar-me aos universitários lisboetas, houve por bem de enxertar as seguintes palavras, adrede escritas pelo professor J. M. VILHENa Barbosa de Magaldhães, catedrático de direito comercial:

"Waldemar Ferreira, quer como professor, quer como advogado, é um verdadeiro e autêntico comercialista que alia à cultura pròpriamente juridica a cultura do economista, ao poder de síntese o espírito de observação e análise.

"E êste o depoimento dos seus numerosos livros, onde com igual competência e brilho são tratadas as questões puramente jurídicas e as questões de ordem técnico-comercial, e que vai ser confirmado pelas conferências cujas súmulas revelam $\mathrm{o}$ espirito superior do jurisconsulto. Baseado no estudo da vida e através das instituições jurídicas, Waldemar Ferreira eleva-se aos momentosos problemas da politica jurídica e social.

"Orientado por Vivante e Rocco, o Dr. Waldemar Ferreira conhece a fundo os institutos econômicos, que o direito comercial rege; e como comercialista erudito não ignora a vida comercial em tôdas as suas manifestações.

"Waldemar Ferreira, sem prejuizo da cultura juridica geral, que possui em alto grau, conseguiu especia. lizar-se como poucos; tem sido sempre professor de direito comercial; tem advogado sempre no fôro comercial, tem escrito exclusivamente sôbre direito comercial, sôbre questōes jurídico-comerciais que versa com profundeza de conhecimentos e com critério superior.

"Em contacto permanente com a realidade da vida e com as obras dos mais notáveis comercialistas de todo o mundo, o seu espírito está admirávelmente preparado para dar o maior rendimento. 
"Se ainda não produziu um grande tratado de direito comercial, nos seus numerosos e excelentes livros tem acumulado os materiais necessários para essa obra, que permita-se-nos dizê-lo — tem obrigação de fazer, para definitiva consagração de seu nome e para grande proveito de todos nós."

“Estas generosas expressões, aqui reproduzidas para pasto de minha pobre vaidade, impregnaram-se-me no espírito. Senti-me na necessidade de corresponder ao apelo, que me alcançara como ondem de comando.

"Preparando as páginas a fim de reeditar o meu livro de preleções, percebi que elas se haviam aumentado tanto que o primitivo curso se avolumara como um tratado. Não evidentemente, "um grande tratado"; mas o desenvolvimento mais extenso das matérias do meu curso na Facudade de Direito da Universidade de São Paulo.

“Dando là publicidade êste primeiro volume, a que se seguirão outros já em preparo, alimento a esperança de servir, antes de tudo, aos meus discípulos; e, com ela, a de poder cumprir com a continuidade de esforço ininterrupto, a espectativa do nobre professor catedrático português.

"Relembrando as honrarias, com que os juristas lusitanos me distinguiram, permito-me o prazer de reiterarlhes, no limiar desta obra, os protestos de minhas gratidão na constância da minha saudade".

85. O pacto de retrovenda $e$ o direito de resgate. Côrte de Apelação do Estado de São Paulo. Comarca da. Capital. Apelação Civel n. 21.701. Sociedade Territorial Estação de São Bernardo Limitada vs. Sociedade Anônima para Venda no Brasil dos Produtos Michelin. :54 págs. - São Paulo Editora Limitada, 1935.

86. As Pilulas Xavier $e$ as anemias verminosas. Questão de marca de fábrica. - Côrte de Apelação de São. Paulo. Comarca da Capital. Recurso crime n. 6.941. 
Ernani Lomba vs. João Gomes Xavier. — 94 págs. — São Paulo Editora Limitada, 1935.

87. O casamento religioso de efeitos civis. - 184 págs. - Tipografia Siqueira. Sales Oliveira \& Cia. Ltda. - São Paulo, 1935.

I. Da Secção - Livros novos, de O Estado de São Paulo, de Plinio Barreto:

"A Constituição Federal"declarou que o casamento será civil mas permitiu que fôsse celebrado perante ministro de qualquer confissão religiosa, cujo rito não contrariasse a ordem pública ou os bons costümes. 0 casamento assim realizado produzirá os mesmos efeitos que o civil desde que, na habilitação dos nubentes, na verificação dos impedimentos e no processo da oposição sejam observadas as disposições da lei civil e seja êle inscrito no registro civil. Este será gratuito e obrigatório. 'A' lei estabelecerá penalidade para a transgressão dos preceitos legais atinentes à celebração do casamento. A Assembléia Legislativa, para completar o texto constitucional, fez uma lei que regulasse o casamento e que estabelecesse penalidades para a transgressão de seus preceitos. Não se imagina a celeuma que essa lei provocou. Na Assembléia combateram-na ivários. juristas e o chefe do executivo acabou vetando-a. Por que êsse barulho? Porque, tratando-se do ato matrimonial, o projeto dispôs que a solenidade se realizaria na Igreja ou templo, ou outro local designado ou admitido, pelo celebrante, a portas abertas, perante testemunhas, parentes, ou não, dos contraentes e na forma do rito da religião adotada. Esse dispositivo pareceu inconstitucional ao presidente da República. Com êle meteu-se o legislador na vida íntima das religiões, o que não é permitido pela Constituição. Regular o ato da celebração do casamento religioso, dispôr a respeito das circunstâncias que devem cercar a cerimonia religiosa, declarou um ilustre deputado na Assembléia, é promover a relação de dependência cuja manutenção com qualquer culto ou igreja o art. 17, n. III, da Constituição, veda à União.

"A essas observações, inclusive as do veto, replicou 0 relator da Comissão de Justiça, o deputado paulista, sr WALDE- 
MAR Ferreira, que, além, de sacramento ou cerimônia religiosa, o casamento é ato juridico. Enquadrado no sistema do direito civil brasileiro, compete à lei ordinária, certamente, disciplinar a celebração do casamento religioso, determinando as formalidades desta, contanto que não invada a parte litúrgica da solenidade, nem a dificulte ou restrinja de qualquer modo. Estabelecendo essas formalidades, o poder público não legisla sôbre o direito desta ou daquela confissão religiosa, nem estabelece com ela relação de aliança ou dependência. Se a Constituição permitiu a ministros de confissões religiosa celebrar o casamento e deu a essa celebração efeitos juridicos, a lei ordinária, prescrevendo disposições e determinando formalidades, tendentes a aumentar a segurança juridica do casamento, não impõe às confissões religiosas provvidências que thes restrinjam a liberdade de culto ou lhes afetem o ritual, mas apenas colabora com elas em prol do interêsse público, para cercar de maiores garantias o ato matrimonial. Se a Constituição manda que a lei ordinária estabeleça penalidades para a transgressão dos preceitos legais atinentes à celebração do casamento, reconheceu implicitamente que a lei ordinária pode estabelecer preceitos atinentes ao ato matrimonial. Não é verdäde que a lei haja regulado $o$ ato religioso da celebração do casamento. Fez apenas exigência de certas formalidades exteriores para a sua celebração; destinadas a imprimir-lhe publicidade e autenticidade. A parte puramente religiosa do ato foi respeitada. Ficou a cargo do celebrante.

"Lendo-se com atenção o projeto, os debates e o veto presidencial, chega-se à conclusão de que o vício de inconstitu. cionalidade, de que o acoimaram, não o sofre o projeto. Com as providências, que determinou, nenhuma incursão praticou na parte litúrgica da cerimônia. Não se podia recusar ao legislador a faculdade de estabelecer preceitos atinentes à celebração do ato, que fôssem aplicados tanto ao casamento civil como ao religioso. O casamento no Brasil continúa a ser civil ainda quando celebrado por sacerdote e é a lei civil que traça as formalidades a que deve obedecer. O sacerdote só entra em cêna para substituir o juiz de paz, no momento de celebração. Nesse momento, em vez de seguir o rito da lei civil, segue o da sua confissão religiosa. Foi essa a unica concessão de acôrdo com as normas traçadas pela lei civil. As formalidades, que o projeto exigiu, para a cele- 
bração do casamento, são de interêsse geral. Dizem respeito à ordem pública. Se entrarem em conflito com o rito de qualquer confissão religiosa, é porque êsse rito contraria a ordem pública e, nessa hipótese, a confissão religiosa não poderá gozar do favor constituicional da celebração de casamentos. A intervenção de sacerdotes no ato da celebração é um favor às confissões religiosas, mas êsse favor não altera o caráter civil do contrato. Dá-lhe apenas um ligeiro colo. rido de sacramento. Curiosa seria a instituição civil do casa-: mento se, precisamente, no ato capital, que é a celebração do matrimônio, a lei civil nada pudesse estabelecer para assegurar a autenticidade do ato, isto é, suas condições essenciais para a sua validade. Outros pontos do projeto provocaram controvérsias. Mas o ponto principal foi êsse. E num volúme sob o titulo - $O$ casamento religioso de efeitos civis, o sr. Waldemar Ferrerra expõe, metodicamente, com a habitual clareza, tudo quanto houve na Assembléia a êsse respeito, reproduzindo, na integra, várias peças e discursos. o leitor que se queira enfronhar bem no assunio, encontrará nêsse volúme tudo de que necessite para completo conhecimento da matéria."

II. De Apollinaris, de Roma:

"Cum ex art. 146 Constitutionis Brasiliae graves quaestiones sint circa relationem inter matrimonium religiosum et civilem actum, Exc.mus W. FerRerra legem quamdum proposuit, qua haec res omninio regeretur, variique casus aptum norma invenirent; propositam vero legem etsi a coetibus legislativis approbatum, praeses Reipublicac vetuit, ita ut adhuc promulgata non sit.

"Exc.mus W. Ferreira, hoc volumine dum exponit et illustrat suas propositiones, accuratis commentariis et explicationibus, refert etiam varia fata quae apud legislativos coetus et postea apud Reipublicae praesidem lex proposita passa est".

88. A renovação judicial dos contratos de locação de prédios ocupados por estabelecimentos comerciais. - Côrte de Apelação de São Paulo. - Comarca da Capital. 
Agravo de petição n. 4.518. Daniel Dhelomme vs. Sales Oliveira \& Cia. Ltda. - 87 págs. - Tipografia Siqueira. São Paulo, 1936.

89. O estado de assembléia e o estado de guerra. Separata da Revista da Faculdade de Direito da Universidade de S. Paulo, vol. XXXIII, onde não chegou a publicarse por imposição da ditadura fascista, juntamente com trabalho de Juan Carlos Rebora, professor da Universidade de La Plata, Republica Argentina. - 21 págs. - São Paulo, 1937.

\section{8}

90. O loteamento e a venda de terrenos em prestacões. - Emprêsa Gráfica da Revista dos Tribunais. - São Paulo, 1938.

Primeiro volúme - Decreto-lei n. 58, de 10 de dezembro de 1937. - Texto e comentários. - 309 págs.

Juan Carlos Rebora, professor da Faculdade de Direito e Ciencias Sociais da Universidade de La Plata, assim se exprimiu sôbre êst'e volume:

"Loor a sua gran obra de jurista!

"Veo que la casación de sus poderes de diputado no ha restado ni un adarme a su capacidad de acción o a su entusiasmo de organizador. Y celebro que la demonstración me haya sido ofrecida por un nuevo trabajo de legislación, en que ha brindado V. a su pais y especialmente al bienestar de las clases modestas la contribución de su experiencia y de su sabiduría.

"Yo pienso que en la madurez de la vida, floridamente alcanzada por V., las grandes obras no son solamente los tratados extensos y eruditos. Una iniciativa, una solución, un golpe de tímón pueden cobrar en ciertas circunstancias los perfiles de una gran reforma social. Y asi, del punto de 
vista de su significación y transcendencia, yo comparo su proyecto de 9 de junio de 1936, con sus mejores obras, que tanto respeto me merecen, y doy a la elaboración ulterior, expresada en las ampliaciones y comentarios que su nuevo libro encierra, el walor de una magnifica realización de estadista.

"O loteamento e a venda de terrenos em prestaçöes es materia que ha sido considerada aqui por diversos proyectos presentados al Congreso, de los cuales ninguno ha sido con franco aplauso. El problema ha preocupado tanto que una corporación administrativa llamada Comisión Nacional de Casas Baratas decidió provocar, a mediados de 1936, o sea justamente cuando V. presentaba su proyecto, una Conferencia en que.se debatiria el asunto (la cual no llegó a reunirse) y me tocaba a mí, como presidente de una de sus secciones, presentar un nuevo proyecto. Con esto quiero decirle que he debido informarme de todo lo que sobre la materia existe y que no conozco nada tan enjundioso y tan original como su trabajo, cuyas dificultades, además puedo medir. La felicitación que le lleva esta carta manifiesta mi mucha admiración y mi franco aplauso".

Segundo volúme - Decreto n. 3.079, de 15 de setembro de 1938. - Texto e comentários. - 156 págs.

$\mathrm{Na}$ secção - Livros novos, que por muitos anos manteve n' O Estado de Sx̃o Paulo, bordou Plinio Barreto estas considerações a propósito dêste segundo volume:

"Ao decreto-lei que, em dezembro de 1937, dispôs sôbre o loteamento e venda de terrenos em prestações, dedicou o professor Waldemar FerReira largo e substancioso comentário de que, faz alguns mêses, dei noticia nestas colunas. Aquêle decreto foi regulamentado por outro em setembro do ano passado. Entende o dedicado professor que ficaria incompleto o trabalho iniciado se também não comentasse êsse novo decřeto. E, na verdade, ficaria. Muitas alterações de fundo trouxe o decreto de setembro de 1938 ao decreto de dezenibro de 1937. No conflito entre êles qual deve prevalecer, uma vez que o segundo teve por intuito apenas regulamentar o primeiro? Se se tratasse de legislação feita no regime constitucional de outróra, não haveria dúvida alguma de que, em caso de conflito entre o regulamento e a lei, o que devia prevalecer era a lei. No regime atual, em que o 
Executivo está investido de poderes legislativos, êsse conflito, praticamente, não existe. Se o regulamento modifica a lei o que deve prevalecer é o regulamento. As datas é que decidem, pois o poder que expediu o regulamento tinha competência para alterar a lei. Dar-se-á apenas nessa hipotese um erro de técnica pela mistura que no regulamento se estabelece entre disposições de caráter normativo e disposiçōes de caráter regulamentar.

“O professor Waldemar FerReira aponta e critica as alterações que o regulamento introduziu na lei. Essa crítica é antecedida de outra sôbre a função legislativa e regulamentária em face da carta politica de 1937. As duas ordens de crítica confirmam o conhecimento seguro do assunto que o ilustre professor já havia denunciado no primeiro volúme e a independência e coragem do seu espirito. Os problemas jurídicos que os novos decretos suscitam são em número elevado. O sr. Wardemar Ferreira estuda os principais e as soluções que sugere são, quáse sempre, bem fundamentadas».

91. Ação de dissolução de sociedade. - Tribunal de Apelação de São Paulo. Comarca da Capital. Agravo de petição n. 2.884. Manuel Ferreira Carneiro vs. Ary Rebello de Lima e João de Quadros Junior. - 116 págs. Emprêsa Gráfica da Revista dos Tribunais. - São Paulo, 1938.

92. Código das sociedades comerciais. - 401 págs. Emprêsa Gráfica da Revista dos Tribunal. São Paulo, 1938.

Do aparecimento diêste livro O Estado de São Paulo deu esta noticia:

"A parolagem excessiva dos parlamentos desmoralizouas. Todavia, fóra do recinto, longe da tribuna, há nêles uma zona de trabalho intenso e fecundo. E' a zona onde funcionam as comissões. São disso atestado irrefutavel, no que concerne à extinta assembléia brasileira, os dois volúmes de trabalhos parlamentares que o professor Waldemar Ferreira acaba de publicar. São quáse todos trabalhos feitos nas comissões.

"O primeiro, a que deu o título - Código das sociedades comerciais, começa por um estudo sôbre essas sociedades. 
Esse estudo, provocado por um projeto que remodelava as sociedades anônimas, tomou as proporções de um código. 0 texto é acompanhado de anotações que o esclarecem e justificam.

"A êsse trabalho segue-se uma análise dos contratos de compra e venda de coisas móveis a prestações, assunto de que, há muitos anos, o ilustre professor havia tratado em artigos de revista. Apareceu, na Câmara, na última assembléia legislativa, um projeto de lei estabelecendo nórmas para os contratos dessa natureza. Esse projeto deu ensejo ao sr. Waldemar Ferreira para rever a matéria e traçar extensa análise do projeto.

"Nêsse estudo encontram-se observações muito interessantes sôbre o pacto de reserva de dominio, sôbre a convenção de locação no contrato de compra e venda a crédito e sôbre outros aspectos dêsse instituto.

"O sr. Waldemar Ferreira condena tanto o projeto cujos defeitos aponta, como o substitutivo que, pela imprensa, propugnou o sr. Philadelpho Azevedo, distinto professor na Faculdade de Direito do Rio de Janeiro. Combateu-os ambos porque, a seu ver, viriam a favorecer a má fé dos compradores e proscrever dos contratos de compra e venda a crédito o pacto de reserva de propriedade. Mais do que isso! desfazia-se de pleno direito o contrato de compra e venda, o qual se resolveria, pela móra do comprador, no de locação.

"Examina, depois, o professor Waldemar Ferreira o projeto de criação dos cartórios dos síndicos judiciais, atacando-o com vigor.

"A organização das sociedades de economia coletiva, sociedades que têm sido, infelizmente, uma fonte inexaurivel de escandalos e prejuizos, deu-lhe ensejo para um estudo minucioso do assunto e para o oferecimento de uma série de sugestões de carater prático, destinadas a proteger a boa fé do público contra a esperteza dos que exploram a economia popular.

"Fecha o volume um trabalho sôbre a proibição de fornecimento de informações e publicidade de títulos protestados. Nesse trabalho o sr. Waldemar Ferreira combate a idéia, que chegou a concretizar-se em projeto de lei, de se proibir o fornecimento de informações sôbre títulos levados a protesto, antes que o protesto seja tirado. $O$ que prejudica o comerciante, friza êle, não é a divulgação de ter 
sido o titulo levado a protesto. o que o prejudica é não haver efetuado o pagamento no dia do vencimento. A divulgação da impontualidade não acarreta perigos. Antes Só vantagens traz para o comércio, principalmente em vista dos efeitos de ordem econômica e juridica da mesma decorrente. Ciom a proibição da publicidade se tornaria impossivel o protesto quando o devedor não fose encontrado. Como fazer o oficial a intimação por edital, se a lei lhe proibe o fornecimento, de qualquer maneira ou forma, de indicaçōes, informações. certidões ou listas de títulos ou letras, antes de lavirados os respectivos instrumentos de protesto?"

93. Principios de Legislacão Social e Direito Judiciário do Trabalho. - Volume primeiro. - 269 págs. — São Paulo Editora Limitada, 1938.

Sumário:

Introdução. - Capitulo I, As primeiras leis sociais brasileiras. - Capitulo. II, O Patronato Agrícola. - Capitulo III, Os Tribunais Rurais. - Capitulo IV, Os contratos coletivos do trabalho. — Capitulo V, O sindicato ou associação profisional.

Primeira parte — A justiça do trabalho. - Capitulo I, As Comissões Mistas de Conciliação. - Capitulo II, As Juntas de Conciliação e Julgamento. - Capitulo III, A Justiça do Trabalho na Constituição da Repúlblica. - Capitulo IV, a Justiça do Trabalho e o mecanismo judiciario do regime. - Capitulo V, A competência da Justiça do Trabalho. - Capitulo VI, O anteprojeto. - Secção I, A organização judiciária. Secção II, O processo do trabalho. - Capitulo VIII, As conclusōes. - Apêndice: I, A exposição de motivos do Ministro do Trabalho, Industria e Comércio. - II, $\mathrm{O}$ anteprojeto governamental da Justiça do Trabalho.

94. Principios de Legislação Social e Direito Judiciário do Trabalho. - Volume Segundo. - 580 págs. - Livraria Editora Freitas Bastos. — Rio de Janeiro e São Paulo, 1938.

Sumário:

Segunda parte - Decreto lei n. 1.237, de 2 de maio de 1939. Organiza a Justiça do Trabalho. 
Apêndice - I, Decreto-lei n. 1.237, de 2 de maio de 1939. - II. Decreto-lei n. 1.346, de 15 de junho de 1939. III. Notas bobliograficas. - IV, Indices alfabeticos.

- Em Tribunales del Trabajo. Derecho Procesal del Trabajo, publicado pelo Instituto da Diretoria do Trabalho da Universidade Nacional do Litoral, da Republica Argentina (Santa Fé, 1941), escreveu o professor Mariano R. TissemBAUM presidente daquele Instituto:

"El profesor de la Facultad de Derecho de San Pablo, Brasil, Dr. Waldemar M. Ferreira, ha publicado una obra de mérito relevante, con motivo de la organización de la justicia del trabajo en el Brasil.

"La elaboración del actual sistema judiciario del trabajo ha concitado la colaboracion de numerosos juristas en cuanto a las opiniones que previamente se emitieron en la encuesta que organizó el gobierno antes de dar forma definitiva al proyecto de ley, y al comentario que posteriormente a su sanción se ha expresado en diversas publicaciones. Entre ellas se destaca en modo evidente, la del Dr. WALdemar M. Ferreira y como fruto de la misma, surgió el libro de la presente nota.

"La obra se compone de idos tomos aparecidos em años sucesivos, razón por la cual comprenden estos aspectos diversos. En el primer tomo se encara el estudio del anteproyecto sometido al Congresso, en el año 1937, y en el segundo tomo, se comenta el decreto ley del año 1939 que instituye la justicia del trabajo.

"El Dr. Ferreira a modo de prefacio, formula algunas referencias sobre los antecedentes del actual régimen legal de la justicia del trabajo, consignando las iniciativas, los mensajes y el discurso pronunciado por el autor en la Camara de Diputados en el año 1937 en el rebate producido con motivo de la discusión idel proyecto remitido por el gobierno.

"Recife el autor el proceso de la elaboración del proyecto sometido al parlamento, hasta que sobrevino el golpe de Estado de 1937 y posteriormente el decreto ley del año 1939 que organiza la justicia del trabajo, en base a un anteproyecto elaborado por una comisión especial designada por el gobierno.

"El tomo primero comprende en un análisis esquemático el panorama jurídico y social del Brasil antes de Ia 
vigencia del decreto ley de 1939 citado y se exponen con tal motivo las primeras leyes sociales que contemplan el problema del trabajo rural enunciándose la institución del patronato agrícola, la organización de los tribunales rurales de San Pablo - los primeros que se instituyeron en el Brasil - en base a la organización paritaria de los mismos, hasta que se sanciona la Constitución del año 1934 en que se constitucionaliza el principio de la justicia del trabajo en forma separada de la justicia común.

"La convención colectiva del trabajo es objeto de un capítulo especial en que se desarrolla su naturaleza jurídica y su vinculación con la organización profissional en punto a la función $y$ atribuciones que le corresponden, dada la circunstancia de su conexión con las cuestiones inherentes a los conflictos colectivos del trabajo.

"Se inserta más adelante el informe u opinión emitida por el autor en su carácter de presidente de la Comisión de Cionstitución y Justicia de la Cámara de Diputados sobre el mensaje presidencial y el anteproyecto de ley sobre organización de la justicia del trabajo que ha sido comentado elogiosamente por el jurisconsuito Oliveira VIANA al calificarlo como "um curso sintético de la legislación social y derecho procesal del trabajo".

"En el citado informe $\mathbf{u}$ opinión se analiza el carácter de las comisiones mixtas de conciliación vinculadas con la naturaleza jurídica del convenio coletivo, las funciones de las juntas de conciliación y juzgamiento en razón de la competencia para dirimir los litigios del trabajo, las cuestiones $y$ debates suscitados con motivo de la incorporación del precepto de la justicia del trabajo en la Constituición del año 1934, el procedimiento de la misma, los fundamentos que se enuncian en la exposición de motivos y las disposiciones que se consignan en el anteproyecto de ley, en cuanto a la organización de de la justicia y as las normas procesales para la solución de los conflitos individuales e colectivos del trabajo.

"Finaliza el primer tomo con las conclusiones que a modo general formula sobre la justicia del trabajo, transcribiendose la exposición de motivos y anteproyecto de ley que el P. E. deI Brasil sometió al Congresso en el año 1936.

"El segundo tomo de la obra del Dr. Ferreira aparecida un año despues del primeiro, en 1939 y cuando ya se habia dictado el decreto ley del mismo año que organiza la justicia 
del trabajo, se dedica fundamentalmente al comentario del decreto ley citado.

"Precisamente el autor formula una exposición sobre el concepto del derecho judiciario o derecho procesal y luego comenta artículo por artículo el decreto ley de Mayo de 1939. Se analiza asi las referencias, doctrina, en procura de una justa interpretación jurídica y social, de las disposiciones y atribuciones del mencionado decreto ley, de las funciones y atribuciones de las Juntas de Conciliación y Julgamiento y Jueces de derecho; de los Consejos Regionales del Trabajo, de los funcionarios auxiliares de la justicia del trabajo de las atribuciones de ésta a travês de la competencia de los organismos citados, del procedimiento, tanto para los conflictos individuales como colectivos del trabajo, de la ejecución de las sentencias, recursos y penalidades por incumplimiento.

"En la última parte del tomo se comenta en igual forma el decreto ley de Junio de 1939, que organiza el Consejo Nacional del Trabajo, con la institución de las dos Cámaras: de trabajo y de previsión social, consignando la competencia de estos organismos y las normas procesales consiguientes.

Tal es el contenido de los dos tomos, y cabe destacar que, sin ser el Dr. Waldemar Ferreira especialista en la materia del trabajo pues su inclinación juridico lo ha llevado au cultivo de la ciencia juridica comercial, la obra constituye un tratado de suma importancia que se destaca no solo por el analisis que formúla el autor en sus comentarios, sinó, por la amplia versación que revela del tema que encara, abonado con el conocimiento de una amplia bibliografia y la información precisa de los antecedentes que invoca.

"Puede afirmarse que la obra del Dr. Waldemar FerREIRA resulta indispensable para un preciso y cabal conocimiento de los antecedentes y de la organización y funcionamento de la justicia del trabajo en el Brasil".

95. O direito insurrecional do acionista. - Tribunal de Apelação do Estado de São Paulo. Comarca da Capital. Apelação civel n. 5.012. Antonio Izar vs. Coronel Vicente Soares de Barros. - 127 págs. - Emprêsa Gráfica da Revista dos Tribunais, 1939. 
96. Tratado de Direito Mercantil Brasileiro. - Volúme segundo - 0 comerciante. - 393 págs. - Livraria Editora Freitas Bastos. - Rio de Janeiro e São Paulo, 1939.

I. Na Revista de Jurisprudência Argentina, de Buenos Aires, Julio C. Rodrigues Arias escreveu:

"E aparecido el tomo segundo de esta obra que comprende en el "presente libro el estudio del comerciante como sujeto de la actividad mercantil. Inicía el autor su tratado determinando en primer término los elementos que configuran la naturaleza jurídica del comerciante, punto en que se detiene a considerar los diversos sistemas doctrinarios y positivos de calificación del comerciante: el sistema subjetivo, el sistema mixto, el sistema del Código português de 1883, el de 1888, el sistema del Código alemáñ , el sistema formalista, el sistema del Código español de 1885 y el sistema brasileño (capacidad jurídica y profesión comercial).

En el capítulo siguiente el professor FerRedra estudia las condiciones de reglamentación profesional del comercio, los requisitos de su ejercicio (nombre, edad, nacionalidad, domicilio y crédito público), la firma o razón social y su registro, e Registro de comercio y la Juntas comerciales. A continuación se ocupa de la clasificación de los comerciantes, según sus actividades, y de las obligaciones profesionales que le corresponden (registro de sus operaciones, balance anual y archivo de documentación).

En capítulo especial, de gran interés jurídico, trata del ejercicio del comercio por los relativamente incapaces (los menores, la mujer casada y los que se encontran en estado de interdicción). En cada uno de estos casos lleva su análisis al mínimo detalle con el ánimo de poner en claro estas discutidas cuestiones. En este orden de ideas estudia también la prohibición del ejercicio del comercio y su fundamento en cuanto concierne al empleado público, a las corporaciones "manos muertas" y al clero, al fallido, a los corredores oficiales, a los rematadores, a los empleados de comercio, a los cónsules, etc. Asimismo examina en este capítulo, el último del libro, la cuestión que se plantea por el ejercicio del comercio por las mujeres de los afectados por la interdicción en ese sentido. 
Para terminar considera las restricciones convenciona. les, resultantes de un contrato de compraventa de un negocio, por ejemplo, cuando el vendedor pacta con el comprador y se compromete a no ejercer el comercio en ciertas circunstancias y condiciones.

Este trabajo, realizado por el professor FerReira, contiene un nutrido material bibliográfico y documental, lo que, unido al admirable método y claridad de estilo del autor, hacen de la obra un ejemplar walioso y una contribuición notable al estudio de las ciencias comerciales. Es lástima la falta de un índice bibliográfico y de disposiciones legales, de gran utilidad para la consulta."

II. Eis como Plinio Barreto noticiou, na sua antiga secção - Livros novos, d'O Estado de São Paulo, de 5 de agosto de 1939, o aparecimento dêste volume:

"Vai pelo segundo volúme o Tratado de Direito Mercantil Brasileiro que o professor Waldemar Ferreira está publicando. Nêste volúme o ilustre professor expõe toda a teoria relativa - ao Comerciante. Sabe-se que não falta a êsse professor a qualidade primacial nos que se dedicam ao ensino, que é a clareza. A matéria é distribuida com rigor lógico e a exposição é feita em linguagem singela, sem demasias de erudição, ao alcance de todas as inteligências. A doutrina do texto é reforçada, frequentemente, pir anotações em que se recolhe o que de mais expressivo fornece a jusrisprudência dos tribunais. Para que se tenha uma idéia do que, nêsse particular, é o livro, vou citar um caso. Procurando caracterizar o comerciante pela prática dos. atos comerciais, o Sr. WALDEMAR FERREIRA sustenta que basta a pratica de atos de comércio contínua e habitualmente, no exercicio permanente e estavel da atividade intermediária mercantil para que se verifique a existência do comerciante. Dessa prática resulta o habito. Decorre dele, da sua continuidade, a profissão. E esta atribui ao agente a qualidade de comerciante. Adverte, porém, logo a seguir, que nem todos os atos dão êsse resultado. Produzem-no os atos de comércio por natureza, re ipsa, por si mesmos comerciais. A prática de atos de comércio por conexão ou dependência, e mesmo por força ou autoridade de lei, a ninguem confere qualificado mercantil. Comerciante não é, exemplifica, o que tiver o habito de depositar as suas economias em banco e efetuar os seus pagamentos por via ıde chéques. Nem o que 
para servir amigos ou mesmo a sociedade de que faça parte, em dado momento se vir na necessidade de avalizar inúmeros titulos bancarios, por ela aceitos, emitidos ou sacados. 0 exemplo veio-lhe a proposito porquanto, na prática, algumas duvidas têm surgido a respeito. Em nota ao pé do texto, cita um caso elucidativo. Foi o que se deu, no Rio, sôbre o endosso de vários titulos de crédito de uma sociedade comercial, feito pelo gerente. Falida a sociedade, os credores requereram, também, a falência do sócio comanditário, sob fundamento de que, endossando os titulos, exerceu ato de comercio e ficou sendo comerciante. A alegação foi aceita pelo juiz em longo despacho que o sr. Waldemair Ferretra combate. Com as transcrições que faz da sentença e do acórdão, deixa êle o leitor habilitado e formar opinião sobre o assunto.

"A nós, jornalistas, interessam, no livro, as páginas em que o distinto professor mostra quando o jornalista é comerciante e quando não é. A sua doutrina a êsse respeito é a mesma de Césare Vivante. "A publicação de jornal não tem caráter comercial quando o seu proprietário o emprega a seu serviço pessoal, na propaganda dos seus pontos de vista cientificos, politicos ou religiosos; se o exercita, porém, na fórma de emprêsa comercial, empregando a obra de numerosos colaboradores, dividindo-os segundo as varias atitudes, ajustando os subsidios e capitais alheios para a compra de direitos autorais, de máquinas tipograficas para o efeito da publicidade e o que fôr mais, a publicação do jornal póde considerar-se ato de comércio". Nesta última hipótese a emprêsa jornalistica é mercantil e comerciante é o jornalista que a explore, seja o jornal noticioso ou critico, doutrinário ou politico, religioso ou social.

Dos multiplos assuntos que, com o intuito de caracterizar o comerciante, trata o sr. Waldemar Ferreira, quero destacar, ainda, o que se refere à posição do marido e da mulher nas sociedades comerciais. Pode a mulher ser sócia do marido em tais sociedades? A questão é controvertida e não existe na lei impedimento expresso. O sr. WaLdEmar Ferreira toma um partido médio. Será permitida a sociedade mercantil entre os cônjuges se o contrato não entrar em conflito com o regime nupcial, se não ofender o poder marital e se não lesar os direitos dos filhos do primeiro leito. Todas as vezes que o contrato social implicar modifi- 
cação no regime de bens do casamento, a sociedade entre os cônjuges não deverá ser permitida.

"Todos os seus modos de ver, o sr. Waldemar Ferreira os sustenta com argumentos precisos, e não os sustenta jamais com excesso de palavras. A sobriedade na argumentação é uma das suas virtudes; e essa virtude concorreu, de certo, para o prestigio que o professor adquiriu entre os alunos. As qualidades didáticas dêsse tratado fazem lamentar que, tão cedo, se encerrasse a carreira do professor".

97. Compêndio de Sociedades Mercantís. - Doutrina, formulário e texto do decreto-lei n. 2.627, de 26 de setembro de 1940. - 644 págs. - Livraria Editora Freitas Bastos. Rio de Janeiro e São Paulo, 1940.

Da Revista del Colegio de Abogados de La Habana (Cuba), ano IV, Abril-Junio 1941, vol. IV, pág. 140, é êste estudo critico do professor Ernesto Dihigo, da Faculdade de Direito da Universidade de Havana:

"Con esta obra nos ofrece el distinguido mercantilista y profesor brasiléño una nueva versión de parte de otra suya publicada por vez primeira en 1919: el Manual del Comerciante, que ha logrado alcanzar dos ediciones más, una en 1923 y otra en 1929. Agotada ya esta última, dispúsose el autor a preparar la cuarta, com las modificaciones neccsarias; pero, según el mismo expresa, el capitulo sobre las sociedades mercantiles se alargó tanto, que fué preciso consagrarle un tomo separado, que es éste que ahora tenemos el placer de comentar. Los hechos de la vida jurídica por una parte, y las nuevas leyes mercantiles del Brasil, por otra, dieron un material abundante y de interés, material que, cuidadosamente estudiado, habilmente distribuido e inteligentemente analizado por el professor Ferreira, constituye el contenido del libro.

"No es un tratado de sociedades mercantiles, tal como estamos acostumbrados a concebir esa classe de obras, sino un libro que, em forma orgánica y metódica, estudia muchos de los problemas que puede ofrecer ese sector del derecho mercantil. Casi un centenar de cuestiones, muchas de ellas 
abarcando aspectos diversos, comprende el libro, cuestiones que, para mayor claridad, han sido agrupadas formando los diferentes capitulos que integrarian un tratado sobre sociedades.

"La obra está escrita en un estilo claro y atrativo. Tiene la doble ventaja de ser" asequible por la forma sencilla de su exposición, al mero comedciante que quiera ilustrarse sobre los problemas que le afecten, y de conservar al propio tempo gran interés para el jurisconsulto, pues en ellas encontrará las opiniones autorizadas del autor. Este revela, en todos los momentos, sólida preparación y gran sentido jurídico, que lo llevan a enfocar y resolver con justeza los problemas que se plantea. El libro contiene, además, modelos ide escrituras de las diversas clases de companias y el texto del decreto-ley 2.627, ya aludido. La bibliografia citada, como era de esperarse, dada la lindole de la obra, es escasa, y se contrae, en su mayor parte, a produciones brasileñas.

"Prueba de que el autor sigue cerca el movimiento jurídico contemporáneo, la encontramos en las páginas del prólogo en que hace referencia a la transformación sufrida por las compañias anónimas em Alemania, particularmente por la ley de 30 enero de 1937, que restó importancia a las asam. bleas de accionistas y robusteció la posición de los órganos ejecutivos, como reflejo de los cambios políticos ocurridos en dicho pais, a virtud de los cuales quedó abolida la democrácia y entronizados la dictadura y el totalitarismo.

Ese hecho sintomático fué la culminación de un largo proceso evolutivo, la cual, en 1933, consagró interesante monografia el Professor Joaguim Garrigues de la Universidad Central (Madrid). Las ideias democráticas del siglo XIX, cuya influencia en el derecho privado fueron admirablemente estudiadas por Georges RIPERT en 1936, hicierom que las anonimas se organizaran siguiendo los mismos principios en que se inspiraban las asambleas y entidades públicas dominadas por el criterio mayoritario. Es natural que, al cambiar la organización de algunos pueblos de Europa, el cambio se reflejara en el derecho privado, y que la crisis, de la demócracia, primero, y su total supresión después, hayan trascendido al régimen de las compañías anónimas. El Estado regido por un sistema de principios dictatoriales, de mođo insensible tiende a suprimir toda manifestación democrática, 
aunque sea en las asambleas de una compañía anónima, mucho más si la corriente socialista ha llevado a concebir esa clase de entidades como un órgano del grupo social.

"El Profesor FerReira tiene una destacada personalidad en su pais, no solo en el campo intelectual, sino también en el de vida pública, en la que ha ocupado altas posiciones oficiales. Su produción jurídica se iniḉó en 1919, con la publicación de varios estudios, uno de los cuales fué el Manual del Comerciante antes citado $\mathrm{y}$ se ha mantenido de modo continuo desde entonces, dando a luz, entre otras, las siguientes obras que lo acreditan como uno de los primeros mercantilistas de nuestra América: Sociedades por Cuotas (1919-1925), Código de Sociedades Comerciales (1938), Curso de Derecho Comercial (1927) Tratado de Derecho Mercantil Brasileño (1934) etc. En 1925 comenzó su carrera profesoral, como docente libre, en la propia Universidad de São Paulo, en la que hoy ¿desempeña la cátedra de derecho mercantil".

\section{1}

98. Renovação judicial de arrendamento. - Supremo Tribunal Federal. São Paulo. Recurso extraordinário n. 5.470. Martini, Leonardi \& Cia. Ltda. vs. Real e Benemerita Sociedade Portuguêsa de Beneficência. - 32 págs. - Tipografia Siqueira. Sales Oliveira \& Cia. Ltda. - São Paulo, 1941.

\section{2}

99. Compêndio de Sociedades Mercantís. - Segunda edição revista e aumentada. Livraria Editora Freitas Bastos. Rio de Janeiro e São Paulo, 1942.

Volume primeiro - Sociedades de Pessoas, - 527 pags.

Volume segundo - Sociedades Anonimas. - 509 págs. Volume terceiro - Sociedades Anônimas. - 438 págs.

Sôbre esta nova edição aduziu Eduardo J. Couture, professor da Faculdade de Direito da Universidade de Mon. tevideo, êstes comentários: 
"Este compendio ya no es compendio sino tratado. El ompendio es la historia, el precedente, como quien dice la turora de este esplendoroso dia. El libro ya es tratado de la mejor especie y calidad, sencillo y pulcro, de largas vistas y minuciosa información.

"Yo me atreveria a decir que por la promisora conciliazión entre las lineas esquemáticas del tratado y la abundania y sentido práctico de los ejemplos, poderia asimilarse a los case book de los autores americanos. Sólo que su libro tiene, además, le espléndida visón sistemática y la preocupa:ión fundamental de los problemas.

"Como es natural esta impresión mia fluye de la comparación que he tenido el gusto de hacer entre la primera y segunda edición. El libro ha crecido como la bola de nieve y estoy seguro que seguirá creciendo para felicidad suya y bienestar de los abiogados del Brasil.

"Además, hay, pir último, un punto que no quiero silenciar: es la forma tan sutil como ud. puede conciliar el caracter brasileño y universal, al mismo tiempo, de su libro. EJ panorama universal. Su utilidad, por ejemplo, en nuestro panorama nacional no oscurece en ningún momento el gran país es evidentíssima."

100. Fixação do aluguel na renovatória judicial de arrendamento. Tribunal de Apelação de São Paulo. Primeira Câmara. - Comarca da Capital. - Processo n. 15.169. - Sales Oliveira \& Cia. Ltda. vs. Daniel Dhelome. - 32 págs. - Tipografia Siqueira. - São Paulo, 1942.

101. A inadmissibilidade da execução de sentença pelo próprio recorrente. - Tribunal de Apelação de São Paulo. Comarca da Capital. Embargos n. 21.230. Daniel Dhelomme vs. Sales Oliveira \& Cia. Ltda. - 13 págs. - Industria Siqueira. - São Paulo, 1944.

De Jurisprudencia Argentina, de Buenos Aires, ano VII, de 10 de setembro de 1945: 
"Trátase de un fallo del Tribunal de Apelación de San Pablo sobre aplicación de ley de alquileres, que estabiliza los mismos al importe de lo percebido en 31 diciembre de 1941. El dictor FerReira expone las razones de las dos embargados, locatários, y de las acciones de renovación de contrato y de consignación de los alquileres.

"Sostiene que en caso ocurrente no se efectua la ejecución de la sentencia por simple registro del mandado, y que no basta su transcripícón pura y simple. Considerado iliquido el quantum de los alquileres y, juzgada la acción de consignación de los mismos, solo la liquidación judicial decidirá desde quando tiene el recurrente derecho al aumento de precio de la locación".

102. Instituições de Direito Comercial. - Livraria Editora Freitas Bastos. - Rio de Janeiro e São Paulo, 1944.

Primeiro volume - Proêmio. - O estatuto do comerciante e da sociedade mercantil. - 509 págs.

Na secção - Resenha de livros, de Verbum, ano I, tomo I, fasc. 2, de setembro de 1944, das Faculdades Cotólicas do Rio de Janeiro, deu conta o Professor Gudesteli PIRES da publicação dêste volúme:

"O Professor Waldemar Ferreira tem o privilégio de 'Iltrapassar os limites do tempo ou as contingências da capacidade mental de trabalho.

"Consegue fazer a divisão das horas de cada dia entre um movimentado escritório de advocacia, uma cátedra exercida com assiduidade e uma produção constante de livros de direito comercial.

"Só neste ano as letras juridicas lhe ficam a dever duas valiosas contribuições: o primeiro volume do Tratado das Debêntures, de que faremos um comentário oportunamente, e esta primeira parte das Instituições, de que ora nos ocupamos.

"Neste volume inicial, aquêle Professor trata do Prốmio, do Estatuto do Comerciante e do Estatuto da Sociedade Mercantil.

"No prefácio o autor declara, modestamente, que êsse novo trabalho é apenas um "curso sumário e sintético, đe satureza didática." 
"Anuncia que aprovveitou, na feitura dêsse livro, dando-lhes maior desenvolvimento, as notas de suas preleções do último triênio.

"Quando fôsse apenas isso, não temos, no momento, um compêndio que sirva para a orientação dos estudantes mesta dificil matéria do curso.

"Na realidade, porém, as Instituições de Direito Comercial do Professor Waldemar Ferreira transcendem de muito essa simples diretriz de um curso didático.

"O livro serve para os estudantes de todas as idades, ministra as primeiras noções aos principiantes, nas Faculdades de Direito, mas constitui também manancial precioso para advogados e juizes pela sistematização de vasto cabedal de iconhecimentos indispensáveis à vida cotidiana do comércio e do fôro.

"No Proêmio, estudam-se o conceito e a formação histórica do direito comercial, seus elementos caracteristicos e suas divisões, o conteúdo dêsse ramo do direito privado, suas fontes e metodologia.

"O Titulo segundo cuida do Estatuto do Comerciante, desdobrando-se em três capitulos, com as seguintes epigrafes: a configuração juridica do comerciante, a regulamentação profissional do comércio e as obrigações profissionais do comerciante.

"O Titulo terceiro estuda o Estatuto da Sociedade Mercantil, iniciado com a analise da personalidade juridica e dos tipos de sociedades, descrevendo, como sociedade-tipo, a de nome coletivo, e, em seguida, as variantes dêsse especime.

"Passa a resumir magistralmente, num só capitulo, tudo quanto de essencial se possa dizer quanto às sociedades por açōes.

"Encerra êsse titulo e, com êle o primeiro volume da obra, descrevendo a sociedade de capital variavel, isto é, a sociedade cooperativa.

"Chega-se, com pesar, ao fim dêsse primeiro volume. Lamenta-se que a obra ainda não esteja completa. Grande é a expectativa pelos volumes que se devem seguir.

"Têm, afinal, os nossos estudantes de direito um guia e uma orientação sistemática para suas investigações e para seus primeiros passos nessa dificil e utilissima disciplina". 
Segundo volume $-O$ estabelecimento comercial. As operações mercantís e os títulos de crédito. -699 págs.

103. Tratado das Debênturas. - Primeiro volume. 385 págs. - Livraria Editora Freitas Bastos. - Rio de Janeiro e São Paulo, 1944.

Na secção bibliográfia da Revista de Derecho, Jurisprudencia e Admininistración, de Montevideo, traçou o Dr. JoGRe PEIRANo Facio êstes icomentarios:

"Es preciso conocer la escasa bibliografia que existe en la literatura ibero-americana sobre el tema de los Debêntures para apreciar debidamente el esfuerzo que significa la publicación de este tratado, cuyo primer timo comentamos. Por eso, sus estensos desarrollos explayados con el estilo, empero conciso del autor, revisten un interés singular.

Este primer volumen se divide en tres partes fundamentales.

En la primera se exponen las nociones cardinales de los empréstitos por emisión de obligaciones negociables, destacándose sus características generales (origen, historia, particularidades económicas y jurídicas y estado de la legislación sobre el tema). Subintra luego en el plan de la obra el capitulo que inicia el estudio del "mecanismo de la operación", es decir, del conjunto de actividades jurídicas $\mathrm{y}$ técnicas que es preciso realizar para emitir las obligaciones negociables. Finalmente, en la tercera parte se trata de las consecuencias a que da lugar la inobservancia de los debidos requisitos $\mathrm{y}$ formalidades prescritos para Ia emisión de las obligaciones. Estas dos últimas partes se hallan intimamente vinculadas, puesto que el autor, con tino singular, ha enfocado la una y la otra como lo sano y lo patológico en el proceso de la emisión de los "debentures": Acompañan al texto, por vía de apéndice una recopilación de la legislación brasileña sôbre el punto y numerosos formularios.

Aún cuando el derecho positivo sobre el que trabaja el Dr. Ferreira presenta particularidades que no son de recibo en nuestro ordenamiento jurídico (v. g.: el carâcter necesariamente privilegiado del título "debenturístico"; la imposibilidad de que existan "debentures" nominativos, 
etc.), se contiene en la obra gran acopio de elementos referibles a problemas que son de mucho interés en nuestro derecho y que, sobre todo, será indispensable tener en cuenta el día en que dicte la ley básica en la materia (p. ej.: problemas relativos a si el Directorio puede, por autoriza:ión de simples cláusula estatutaria, disponer la emisión de "debentures"; a la situación en que se encuentran los nmpréstitos externos frente a las disposiciones legales nacionales; a la importante teoría de las nulidades en materia de "debentures"; etc)."

Nãa ficou nisso o jurista uruguáio. Dirigindo-se ao untor do livro, em carta, ainda teceu considerações dêste raipe:

"Su libro me parece - estimado profesor sencillamente magnífico. Hace poco, por circunstancias gue Vd. ya conoce, tuve oportunidad de revisar la bibliografía nacional y extranjera sobre obligaciones negociables. Créame - porque soy sincero - quando le digo que no abrigo la menor duda al pensar que su obra constituirá una etapa fundamental en el estudio de la materia, y que devendrá libro de consulta obligado para todos los que deseen conocerla a fondo.

"La novedad de algunos temas que Vd. trata (v. g.: la "debenture" mixta, o convertible en acciones), la minuciosidad con que han sido tratados los temas más importantes, que da a su obra el inmenso valor práctico de un tratado de jurisprudencia, y la altura conque Vd se desenvuelve afinando algunos iconceptos doctrinarios, dan a su tratado una jerarquía intelectual que rara vez se encuentra en la diteratura jurídica ibero-americana.

"Me parece que la parte culminante de su obra es la última, en que trata de las sanciones a la inobservancia de los requisitos necesarios para la emisión de los debentures. Creo que Vd. ha dado en el "clavo" en esta materia tan dificil de nulidades, y me parece que no es mucho atrevimiento decirle que considero que el magnifico desarrollo que se inicia en la pág. 225 de su obra le compromete a escribir una monografia sobre la "Teoría general de las nulidades en materia de Debentures". 
104. Apelação Civel n. 24.500. - Tribunal de Justiça de São Paulo. Comarca da Capital. Banco da América S. A. vs. Favorita Ltda. - Parecer. - 51 págs. - Linográfica. - São Paulo, 1945.

105. A adjudicação de bens imóveis em processo de inventário de espólio. - Supremo Tribunal Federal. Estado de São Paulo. Recurso extraordinário n. 8.427. Dr. José de Alcântara Pepe vs. Dr. Mario Mauro. - Parecer. - 38 págs. - Emprêsa Gráfica da Revista dos Tribunais. - São Paulo, 1945.

106. A sublocação parcial do prédio do estabelecimento comercial $e$ a indenização por sua tomada. - Tribunal de Apelação de São Paulo. Comarca da Capital. Apelação Civel n. 24.550. Rothschild Loureiro \& Cia. Ltda. vs. Banco Industrial do Brasil, S. A. - 48 págs. -Tipografia Brasil. - São Paulo, 1945.

107. Os direitos e obrigações do comprador do prédio sujeito a propriedade industrial. - Tribunal de Justiça de São Paulo. Comarca da Capital. Banco Industrial Brasileiro, S. A. vs. Rothschild Loureiro \& Cia. Ltda. 24 págs. - Tipografia Brasil. - São Paulo, 1945.

108. Instituições de Direito Comercial. - Terceiro volume $-A$ indústria da navegação marítima e aérea. - 336 págs. - Lviraria Editora Freitas Bastos. - Rio de Janeiro e São Paulo, 1945.

\section{6}

109. Instituiçốes de Direito Comercial. - Quarto volúme - A falência. - 442 págs. - Livraria Editora Freitas Bastos. - Rio de Janeiro e São Paulo, 1946. 
I. Da Revista de Derecho, Jurisprudência y Administración de Montevideo, dirigida pelo Professor Eduardo J. Couture, ano XLV, n. 1, de 1947, p. 27 :

"Los lectores de esta Revista conocen el comentario que el Dr. Jorge Peirano Facio ha dedicado al Tratado das Debếnturas que el Professor Waldemar Ferreira de la Universidad de São Paulo há publicado hace muy poco tiempo y del que se diera cuenta en t. 42 , p. 128.

"Poco más de un año después el eminente Profesor brasileño entrega al público el $4 .^{\circ}$ volumen de sus Instituciones de Derecho Comercial, dedicado especialmente al tema de la quiebra. Mediante esta obra se lleva adelante una iniciativa de vardadera significación para el Derecho Comercial $y$ en honor a la verdad debe decirse que pocos escritores se hallan, hoy por hoy, dentro del panorama científico americano, como para afrontar una empresa de esta índole. Waldemar Ferreira tiene publicados los dos volúmenes de su Tratado y los tres volúmenes de su Compendio de Sociedades Comerciales y sus Instituciones de Derecho Comercial. Centenares de estudios especiales constituyen una verdadera cantera en la cual el Maestro de la Universidad de São Paulo puede extraer los materiales necesarios para una obra de esta naturaleza.

"A un libro de Instituciones no se llega sino después de un largo proceso de preparación. Aunque parezca mentira es más facil escribir un tratado que unas instituciones. En el primero están todos los materiales; en e] segundo deben estar los mejores materiales. La selección, la condensación y la limitación son los grandes méritos de una obra de esta indole a la que no puede llegar un profesor sino después de árduas instancias de preparación $\mathrm{y}$ de estudios.

"En este volumen relativo a la quiebra, el autor comienza estudiando la evolución del instituto en el derecho brasileño, la naturaleza jurídica del estado de falencia y los sujetos involucrados en la misma. Se continúa con el estudio de la quiebra en sus aspectos procesales, analizán. dose la declaración judicial y el proceso de la quiebra, así como los efectos de la sentencia en cuanto al falido y a sus acreedores. 
"Se examina a continuación la verificación de crédito, la administración de la masa, la posibilidad de acuerdo entre el fallido $y$ sus acreedores mediante los procedimientos del concordata y la liquidación del patrimonio mediante realización del activo con el pago a sus acreedores. Concluye el volumen analizando los problemas conexos a la quiebra: la rehabilitación, los delitos inherentes a la quiebra dictada por los jueces extranjeros".

II. “N'A Tarde, da Bahia, de 27 de abril de 1946, e em sua secção Juizos \& Tribunais, fêz Gilberto Valente êstes comentários:

"Nenhuma publicista, no Brasil, tem enriquecido mais as suas letras juridicas que o comercialista pátrio, professor Waldemar Ferreira. Não há, no direito comercial, recanto mais escondido em que a argucia e a inteligente cultura do conhecido mestre de São Paulo não tenha feito uma pesquisa minuciosa. Os seus tratados, sentindo todos êles a influência das novas orientações do direito no campo da evolução mundial, registram com segurança e clareza a controversia e os pontos pacificos na discussão de um tema de direito.

"Carvalho de Mendonga, que foi um dos maiores juristas patrios, comercialista de singular relevo tem o seu continuador em Waldemar Ferreira, embora bem distintas sejam as duas formações culturais. Enquanto o primeiro reflete uma época de amadurecimento mais tranquila, no campo da investigação dos intrincados problemas, que no Brasil sofriam todavia a inquietude de um INGLEZ DE SOUZA, mais avançado nas teses, incompativeis, às vezes, com o sentido conservador das regras de direito que regiam as relações de mercância, Waldemar Ferreira encontra a ebulição da iépoca atômica, em que certos tabús são destruidos e contestados. Ao publicista do direito que registra a evolução da doutrina, está sempre atrás da face a sequência dos fenômenos jurídicos, a clareza é o primeiro idos predicados. Justamente êsse, Waldemar Ferreira prima em revelar em seus trabalhos. Agora, acaba de dar a lume o quarto volume de Instituições de Direito Comercial, dedicado ao estudo do instituto da falência e da novia lei, aliás defeituosissima lei, ultimos arrancos da ditadura legisferante, cheia de revelações 
totalitárias. 0 trabalho do emérito professor piratiningano moxtra que a sua investigação não se queda, mesmo quandø presta os mais relevantes serviços, com civismo, de que também é professor, à Pátria, como na campanha de democratização promovida pela U. D. N."

110. O crime de falsidade e seus elementos. - Tribunal de Apelação de São Paulo. Comarca da Capital. Recurso criminal n. 14.696. José Lopes dos Santos vs. Sebastião Gomes Alexandre. - 48 págs. - Emprêsa Gráfica da Revista dos Tribunais. - São Paulo, 1946.

111. Instituições de Direito Comercial. - Segunda edição revista e aumentada. - Livraria Editora Freitas Bastos. - Rio de Janeiro e São Paulo, 1947.

Primeiro volúme - Proêmio. O estatuto do comerciante e da sociedade mercantil. - 573 págs.

Segundo volume. - Primeiro tomo - $O$ estabelecimento comercial. - 445 págs.

I. E da autoria do Professor JeAN Escarra, da Faculdade de Direito de Paris, esta critica, da secção bibliográfica da Revue Trimestrielle de Droit Commercial, ano I (1948), vol. 1, pág. 206:

“Le savant professeur brésilien, à qui l'on doit de nombreux et importants travaux sur le droit commercial de son pays, publie la deuxième èdition de ses Institutions de Droit Commercial, dont la première avait paru 1944-1945. Ces deux volumes qui seront suivis de trois autres, contiennent l'introduction générale, l'étude du statut du commerçant, des sociétés commerciales et du fonds de commerce. Si l'on tient compte du rapide developpement économique du Brésil et de l'mmense avenir de ce pays, la connaissance de ses institutions commerciales est d'un intérêt évident. Aussi bien les universités brésiliennes font-elles à l'étude du droit commerciale la place qui lui revient: trois années de cours, au lieu des`quelques mois accordés aux commercialistes français pour exposer cette matière à leurs 
étudiants. L'ouvrage de M. W. Ferreira contient un tableau complet et à jour du droît brésilien. L'auteur est très averti de la doctrine étrangère et ses commentaires font également honneur à sa science juridique et a ses connaissances pratiques. On notera dans ces volumes d'interessants indications sur l'évolution du droit commercial brésilien, une présentation vivante de la figure juridique du commerçant, le commentaire detaillé du décret-loi n.o 2.627, du 26 septembre 1940, sur les sociétés anonymes, enfin un étude particulièrement bien venue de la garantie des droits de propriété industrielle".

II. De Sociedades Anónimas. Revista de Derecho Comercial y del Trabajo, ano III, n. 22 (Montevideo 1948, pág. 79) é esta apreciação do Professor SAgunto F. Perez Fontania, professor da Faculdade de Direito da Universidade de Montevideo:

"El Prafiesor Waldemar Martins Ferreira, que ঘn el momento actual es el más grande de los comercialistas brasileños, publica segunda edición notablemente revisada y aumentada, de sus Instituições de Direito Comercial que por primeira vez apareció en el año 1944.

"El volumen primero está destinado al estudio de los problemas generales de derecho con referencia al comercial, su naturaleza, contenido y fuentes del mismo, asi como el estatuto del comerciante, con los acostumbrados prefacios.

"Del de la primera edición destacamos, por tener siempre actualidad para nosostros, las referencias que hace el autor a la enseñanza del Derecho Comercial en la Faculdad de Derecho de San Pablo donde regia un sistema igual al vigente en nuestro país, o sea desarrollar toda la matéria en sólo dos cursos.

"Waldemar Ferreira pregó para que se modificara ese systema y obtuvo que la enseñanza del Derecho Comercial se desarrollara en tres cursos. Para facilitar su estudio a los estudiantes, publicó la primera edición de la obra que comentámos.

"El autor considera que el derecho comercial es un derecho espécial en el sentido de que es peculiar a los comerciantes, pero además autónomo, con matéria propria, 
institutos peculiares $\mathbf{y}$ principios generales, inconfundibles.

"Refiriendose al problema de la unificación del derecho privado réproduce in extenso la nota pasada por Augusto Teixeira de Freitas al Gobierno Imperial, con fecha 20 de septiembre de 18:67, proponiendo dictar un Código General comum a las materias comprendidas en los Códigos Civil y de Comércio y además un Código Civil que se compondria de tres libros solamente, los que se refiririan a los efectos civiles, a las personas y a los derechos reales. La propuesta del gran jurisconsulto no fué acceptada. Pese a ello nos paréce muy bien que el autor haya dado a conocer este interesante documento, destacando que fué Teixeira de Freitas uno de los primeros sostenedores de la tésis de unidad del derecho privado.

"Al tratar de los llamados actos de comércio, Waldemar Ferreira expone claramente su opinión contraria a la teoría de los actos mistos: "el acto es un solo y por lo mismo uno y íntegro".

"El tomo I del volumen segundo está destinado al estudio del establecimiento comercial, dedicando el capítulo primero a los presupuestos del mismo, sua naturaleza jurídica, los conceptos de establecimiento principal, agencias, filiales y sucursales y elementos que lo integran, tratando en distintas secciones del nombre comercial, de la llamada propriedad comercial y de la industrial, y la garantía de los derechos de la propriedad industrial, rubros que comprende de todo lo referente a las marcas, patentes, comentando el Código de la propriedad industrial (decreto-ley n. 7.903 de fecha 27 de agosto de 1945).

"Trata también el autor de los elementos inmateriales, de la venta y prenda del estabelecimiento y de su administración.

"Escapa a los límites de una nota bibliográfica la consideración particularizada de los capítulos de ambos. volúmenes, y de su vasto contenido.

"El autor expone los caracteres principales de los diversos institutos que estudia, e a pesar del caráter de la obra, lo hace con amplia exposición de las doctrinas mas modernas y la legislacion más reciente. 
"Con su estilo característico, compuesto de frases breves y cortantes y afirmaciones categóricas que revelam el carácter combativo del autor y la firmeza de sus convicciones, tanto en el campo científico como en la lucha por la afirmación de los frincipios democraticos de los que el Profesor Waldemar Martins Ferreira es un ardiente defensor, realiza uma obra de gran interés para los estudiosos del Derecho Comercial.

"Las Instituições de Direito Comercial llenan perfectamente la finalidad que se propuso el autor al escribirlas, expresadas en el prefación de la primera edición. Los estudiantes encontrarán en esa obra los principios fundamentales de los diversos institutos que comprende el Derecho Comercial, expuestos con claridad y con amplia infơrmación legislativa, no sólo brasilleña sino extranjera.

"Sin recargar las citas, la obra contiene una rica información bibliográfica referida principalmente a los autores más modernos sin descuidar las obras clásicas de Derecho Comercial”.

112. Instituições de Direito Comercial. - Segunda edição revista e aumentada. - Livraria Editora Freitas Bastos. - Rio de Janeiro e São Paulo, 1948.

Segundo volüme. - Segundo tomo - Os contratos mercantís e os títulos de crédito. - 502 págs.

Publicou Sociedades Anônimas, Revista de Derecho Comercial, editada pelo professor Sagunto F. Perez FonTana, de Montevideo, ano IV (1949), n. 32, p. 35, esta nota:

"Proseguiendo la reedición de su conocida obra, el Profesor Waldemar Martins Ferreira dedica este segundo tomo del segundo volúmen a los contratos comerciales y los titulos de crédito.

"En el capítulo primero trata de los contratos en general, sus características y forma; de los contratos por correspondencia; la oferta al público y la declaración unilateral de la voluntad; el silencio en la formación de los contratos; los contratos tipos y la adhesion contractual y la prueba de los contratos comerciales. 
El capítulo segundo está dedicado a los títulos de crédito y su naturaleza jurídica; la literalidad de los títulos de crédito y la autonomía obligacional; las distintas clases de títulos de crédito: nominativos, a la orden $\mathrm{y}$ al portador, la convertibilidad de unos en otros y el endoso de los títulos de crédito.

"A continuación el autor trata de los contratos en particular y de los títulos de crédito que con ellos se relacionan. En esa forma estudia paralelamente los contratos y los títulos de dinero agrupando bajo ese título, en el capitulo tercero, al contrato de cambio y la letra de cambio y el vale (nota promisoria); el contrato crediticio, la disponibilidad de fondos y el cheque; el contrato de mutuo y los debêntures. El capítulo cuarto comprende los contratos y los títulos representativos de mecarderías, a saber: compraventa y la "duplicata o conta assinada", instrumento este último típico del derecho brasileño, creado originariamente con una finalidad puramente fiscal y que está destinado a hacer efectivo el cobro de las mercaderías vendidas. La "duplicata" es frecuentemente citada en nuestro medio por los partidarios teóricos del conforme obligatorio y decimos teóricos porque, cuando se concretan proyectos y se piden opiniones, la mayoria los recraza por el temor a la doble imposición fiscal y a la pérdida de clientes desde que los comerciantes son reacios a firmar documentos mediante los cuales se les puede llevar facilmente a la quiebra. Juntamente con el transporte trata del conocimiento y el billete de pasaje; con el depósito, los títulos expedidos por los almacenes generales y el billete de mercaderías, imitación de las órdenes de granos "ordines di derrate" de la derogada legislación italiana y que, según el autor, no ha tenido fortuna en su país.

"Dedica el capítulo quinto a los llamados contratos de servicios: el mandato y la comisión, y el capítulo sexto a los contratos de garantia, rubro bajo el cual agrupa a la fianza, el derecho de retención, la prenda y el seguro, terminando el volumen con el capitulo destinado a la prescripción.

"El volumen de la obra del distinguido Profesor de la Faculdad de Derecho de San Pablo, de la que oportunamente dimos cuenta, es una nueva demostración del alto 
valor intelectual de su autor, así como del dominio de la materia que trata $\mathrm{i}$ su inquietud por conocer y exponer, no solamente la legislación más reciente sino también las doctrinas más modernas expuestas en las distintas manifestaciones de la literatura jurídica".

113. Instituições de Direito Comercial. - Segunda edição revista e aumentada. - Livraria Editora Freitas Bastos. - Rio de Janeiro e São Paulo, 1948. Quarto volume A falência. 604 pags.

Da Revue Trimestrielle de Droit Commercial, de Paris. ano I (1948), pág. 780, é esta nota do Professor JEAN ESCARRA:

"Nous avons signalé la publication des premiers tomes de cet important ouvrage (cette Revue, n. 251, pag. 206) La deuxième partie du tome II est consacrée aux contrats commerciaux et aux titres de crédit. En ce que concerne la nature juridique de ces derniers, l'auteur adopte la conception germano-italienne de l'obligation née du titre lui-même et indépendante des contrats sous-jacents. D'intéressants développements sont donnés dans ce volume sur le contrat d'ouverture de crédit, le compte courant, l'émission d'obligations. Quant au tome IV, il est entièrement consacré à la faillite, dont' le professeur FERREIRA présente une remarquable synthèse. On lira avec intérêt les indications fournies (par. 319, p. 34-48) sur la législation brésilienne en vigueur, législation dont le monument le plus récent est un décret-loi no 7.661, du 21 juin 1945, auquel notre collègue ne ménage pas ses critiques. Signalons également les developpement's consacrés aux diverses variétés de concordats reconnues par le droit brésilien: concordat préventif, concordat suspensif. Tout le volume est un important contribution aux recherches de droit commercial comparé. Les tomes I, II (1re et $2 \mathrm{e}$ partie) et IV des Instituições de Direito Comercial contiennent l'ensemble du droit commercial terrestre. Le tome III, dont la 2e édition est en préparation, sera consacré au droit commercial maritime".

114. Tratado de Direito Mercantil Brasileiro. - Segunda edição revista e aumentada. - Livraria Editora Freitas Bastos, - Rio de Janeiro e São Paulo, 1948. 
Volume primeiro - A historia e a doutrina do Direito Mercantil. - 389 págs.

Volume segundo - A teoria dos atos de comércio. 385 págs.

Volume terceiro $-O$ comerciante. -393 págs.

A respeito desta nova edição manifestou-se em carta, o Professor Dr. Raymundo L. Fernandez, da Faculdade de Direito da Universidade de Buenos Aires:

"Tuve el placer de recibir su tratado de derecho comercial, obra extraordinaria que en mi concepto iguala y aun supera a ese monumento de la literatura juridica de su pais que es el Tratado de Direito Comercial Brasileiro de José Xavier Carvalho de Mendonça, que Vd. con tanta justicia elogia. He leido detenidamente su obra, admirando la erudición de que hace gala, puesta de manifiesto en la exposición de estilo claro y preciso, indicando com minuciosidad los antecedentes históricos y jurídicos de las instituciones mercantiles $y$ del derecho positivo vigente; la crítica que Vd. hace de las leyes y proyectos anteriores y de la legislación en vigor $y$ el estudio detenido de los institutos, denota su gran dominio de la matéria.

"Lo felicito sinceramente, estimado doctor, y con toda efusión, porque su trabajo es magnifico, y unido a su multiple y medulosa producción jurídica, en su casi totalidad sobre derecho mercantil, lo revela como el primer comercialista brasileño de la actualidad.

"Me he enterado también de las vicisitudes de orden personal y político que debió suportar en el período de la dictadura, por sus firmes convicciones democráticas y su acción en pro de la libertad, por lo cual yo, amante también de la ley, de la república y de la democracia, le envio mi mas cordial felicitación. Sus conferencias en Lisboa, en esos dias aciagos, son hermosas piezas oratorias, de bello estilo y gran profundidad jurídica.

"El conocimiento más amplio de sus actividades y su producción intelectual, que ya conocía en parte por la lectura de algunas de sus obras, entre otras el volumen relativo a la falencia, de sus Instituições de Direito Comercial, ha aumentado considerablemente mi simpatia hacia su persona, al comprobar que no sólo es un jurista descollante 
y un trabajador incansable sino también un ciudadano integérrimo, demócrata a carta cabal".

115. Instituições de Direito Comercial. - Segunda edição revista e aumentada. - Livraria Editora Freitas Bastos. - São Paulo, 1949.

Terceiro volume - A indústria da navegação marítima e aérea. - 460 págs.

I. Depara-se na Revue Trimestrielle de Droit Comercial, de Paris, vol. II, ano $2^{\circ}$ (1949), pág. 428, este comentário do Professor Jean Escarra:

"Avec ce volume s'achève la publication de la 2ème édition de l'ouvrage de notre collègue de $S$. Paulo dont nous avons signalé la valeur et l'i mp or t a n ce (cette Revue, 1948, no 251, p. 206; n. 121, p. 789). Le livre que nous venons de recevoir traite simultanément de la navigation maritime et de la navigation aérienne. La tendance à assimiler les deux sortes de navigation tend à se repandre. Déja l'Italie s'est donné, en 1942, un Code de la navigation applicable non seulement à la navigation maritime et à la navigation aérienne, mais aussi à celle qui s'exerce sur les eaux intérieures. Les transport's routiers et ferroviaires demeurent seuls soumis aux régles du droit commun du contrat de transport. Cette méthode appellerait une ample discussion, dont les éléments sont fournis par W. Ferreira dans le paragraphe 251 de son irvre. Le navire et l'avion font l'objet de deux chapitres parallèles et leurs procédés respectifs d'exploitations sont traités suivant le même parallelisme. Un mème chapitre traite du contrat de transport maritime et aérien. Les "événements de mer et d'air", l'abordage, l'assistance, le sauvetage, les avaries et les assurances sont ensuite étudiés. Les deux derniers chapitres traitent du prêt à la grosse et de l'hypothéque maritime et aérienne".

II. Redigiu o Professor Mario Ronondi, da Faculdade de Direito de Pavia, esta nota bibliográfica para a Rivista del Diritto Commerciale, ano XLVII (Milão, 1949), pág. 167 : 
"Abbiamo altra volta richiamato l'attenzione del let. tore sull'importante sviluppo che gli studi privatistici hanno avuto nel Sud-America, ed abbiamo anche messo in guarda dal ritenere che la presente fiuritura sbocci improvisa e senza precedenti. Nel caso del Brasile questa opinione sarebbe tanto piú ingiustificata, perché vorrebbe dire dimenticare che già nel corso del passato isecolo il Brasile ebbe giuristi della statura di TeIxeIra de Freitas, di RuI BARBosa, giuristi. che farebbero onore a qualsiasi paese ed ebbero, massime il primo, visioni, per il loro tempo, veramente percorritrici. Ad essi e ad una lunga schiera di giuristi, ancor troppo noti tra noi, si deve il livello veramente notevole della cultura giuridica brasiliana, quale noi possiamo apprezzare di qui, e più nei personali contatti con colleghi eminenti in tutti $\mathbf{i}$ rami delle discipline giuridiche, se si ha avuto, come chi scrive, la fortuna di visitare - accoltovi con indimenticabile cortesie i principali centri culturali del Brasile.

"Tra i continuatori di questa illustre tradizione di giuristi è l'autore di quest'opra che se intitola modestamente Istituzioni di diritto commerciale, anche se per l'ampiezza dello svoglimento, e l'approfondimento della trattazione, l'opra appare come un vero e proprio trattato.

"Per quanto l'unificazione del diritto delle obbligazione, con abolizione di un codice di commercio, abbia avuto fautori in Brasile, prima ancora che in Europa e la proposta di questa unificazione fosse fatta dal TeIXeIRA DE FREITAS - incaricato ufficialmente dalla riforma del codice civile con quasi quattro lustri di anticipo sulla celebre prolusione del VrvalNTE, e tale tendenza si continui nella dottrina sucessiva con INGLez de SoUzA, Brasilio Machado, alfredo Valladão, Carvalho de Mendoniça, fino al progetto del codice delle obbligazione della commissione composta da Orozimbo Nonato, Filadelfo Azevedo e Hahnemann Guimarães, il Waldemar Ferreira, che da parte sua non é fautore dell'unificazione, in conformita comunque del sistema vigente, circoscrive la sua irattazione a quegli istituto che sono compresi nel vigente codice di commercio e che tradizionalmente gli si ricollegano. Il primo volume, dopo un ampia introduzione generale, tratta della condi. zione giuridica del commerciante e delle società commer- 
ciali; il secondo - diviso in due tomi - dell'azienda commerciale, dei contratti e dei titoli di credito. Il terzo volu. me tratta della navigazione marittima e aerea. L'opdra si chiude col vol. IV sul fallimento.

Se la natura dell'opera non consente di entrare in dettagli, riteniamo che soprattutto al lettore europeo particolari interesse presenti la prima parte del vol. II, in cui se tratta della teoria generale dell azienda - concepita come universitas - dei suoi elementi, dei segni distintivi, dell' avviamento e della concorrenza sleale. Questa trattazione - che tocca i problemi di più vivo interesse anche nella più recente letteratura europea - dà il segno nell'organica impostazione dell opera, della modernità e del rigore dogmatico della costruzione del Waldemar Ferreira. Ma questa trattazione interessa lo studioso europeo anche perchè in questa materia si ebbero importanti contributi originali nella dottrina brasiliana - come il noto scritto di Rur Barbosa c. d. cessione dell'avviamento - e perchél il Brasile possiede un testo organico di legge sui brevetti, i marchi, i disegni e la concorrenza sleale (decreto 29 giugno 1934, $n$. 24507) e alla tutela di questi diritti tanta l'importanza é roconosciuta, che la stessa costituzione non manca di farne cenno.

"Nell'insieme si tratta di opera di notevele importanza che entra nella letteratura commercialistica internazionale".

116. Compêndio de Sociedades Mercantís. - Terceira edição revista e aumentada. - Livraria Editora Freitas Bastos. - Rio de Janeiro e São Paulo, 1949.

- Volume primeiro - Sociedades de pessoas. 589 págs.

- Volume segundo e volume terceiro - Sociedades anônimas. - 1.155 páginas.

$\mathrm{Da}$ Revue Trimestrielle de Droit Commercial, vol. II (París, 1949), pág. 574 :

"Nous avons deja signalé plusieurs volumes du savant professeur brésilien, notamment ses Instituições de Direito Comercial (Revue, 1948, p. 206, n. 251, et 798, n. 121) ; le present cuvrage est relatif aux sociétés commerciales. Le premier volume est consacré aux sociétés de personnes; le 
second qui comprend deux tomes comporte l'etude des sociétés anonymes et spécialement du décret-loi $n .0^{0} 2.627$, du 26 septembre 1940.

"Des tables copieuses: tables alphabétiques à la fin du premier et du troisième tome; table par articles du decret-loi du 26 septembre 1940 à la fin du $3.0^{\circ}$ tome; tables analytiques en tête de chaque tome, permettent une utilisation facile de l'ouvrage qui, outre sa portée scientifique et didactique a également une utilité pratique par les formules d'actes insérées à la suite des chapitres qu'elles concernent".

117. El problema del trabajo en la Constitución Brasileña de 1946. - Separata da Revista de Ciencias Jurídicas y Sociales, da Universidade do Litoral, n. 56-57. Tradução do Dr. Alfredo J. Rupreecht. - 22 págs. - Santa Fé, República Argentina, 1949.

Pareceres, artigos de doutrina, notas bibliográficas, conferências, monografias sem número nem conta deparam-se nos seguintes periódicos e revistas:

- Revista de Comércio e Indústria, publicação mensal do Centro do Comércio e Industria de São Paulo, depois Associação Comercial de São Paulo (1915 a 1921);

- Os Anais Forenses, direção de Almachio Dinız (Rio de Janeiro, 1915);

- Revista Juridica, ed. da Livraria Francisco Alves (Rio de Janeiro, 1916 a 1922);

- Revista Brasileira de Legislação e Jurisprudência, dirigida por Afronso Dionysio Gama (São Paulo, 1924 a 1925) ;

- Revista de Direito Comercial, direção de AbamasTOR Lima (Rio de Janeiro, 1931);

- Revista Acadêmica, da Faculdade de Direito de Recife (Recife, 1930 e 1934); 
- Pandectas Brasileiras, dirigidas por Eduardo EsPtNoLA (Rio de Janeiro, 1928);

- Revista dos Tribunais, Publicação oficial dos Trabalhos do Tribunal de Justiça de São Paulo (1917 a 1948);

- Revista da Faculdade de Direito, da Universidade de São Paulo (1926 a 1949);

- Revista Judiciária, Publicação dos Trabalhos do Superior Tribunal de Pernambuco (Recife, 1934);

- Espirito Santo Judiciário (Vitória, 1936);

- Direito Aplicado, dirigida por Pedro Vergara e Prado Kelly (Rio de Janeiro, 1936);

- Revista Judiciária, dirigida por Sylvio Marcondes (São Paulo, 1936);

- Revista do Trabalho (Rio de Janeiro, 1937);

- Justica, de Porto Alegre (1939);

- Revista Forense (Rio de Janeiro, 1947 a 1949);

- Direito, ed. da Livraria Freitas Bastos (Rio de Janeiro, 1940 a 1949 ;

- Mensario Forense, de Belo Horizonte, ano I, vol. II, pag. 1, setembro de 1948 .

- Revista da Ordem dos Advogados, de Portugal (Lisboa, 1947 e 1948);

- Revista da Ordem dos Advogados, Secção de São Paulo (São Paulo, 1948 a 1949);

- Revista de Derecho Comercial, publicação do Instituto Argentino de Direito Comercial (Buenos Aires, 1948)

- Sociedades Anônimas, Revista de Derecho Comercial. Montevideo, ano V, n. 50, de julho de 1950;

- Rivista del Diritto Commerciale e del Diritto Generale delle Obbligazioni, Milão, ano XLVII, setembro e outubro de 1950, n. 9-10;

- Revista de Derecho Privado, Madrid, ano XXXIV, n. 404, novembro de 1950 . 
Inúmeros folhetos, contendo arrazoados forenses, têm sido publicados, editando pareceres de Waldemar Ferreira, entre os quais:

- Um caso de habilitação de herdeira, razões do advogado Aureliano Guimarães, na comarca de Brotas, Nova Era, Emprèsa Editora (São Paulo, 1923);

- Falência de Azevedo, Irmão \& Cia, da comarca de Araguari, Estado de Minas Gerais. - Tip. Aurora. (Araguari, 1925);

- Por causa de uma fazenda, alegações do advogado Abrahão Ribeiro, em ação de Gilberto Sales vs. Dr. Jorge Dumont Vilares, comarca de São Paulo. - Secção de Obras d'O Estado de São Paulo, 1926.

- Sociedade anônima. Convocação da assembléia pelos próprios acionistas. Formalidades substanciais. Memorial do advogado NoÉ Azevedo. - Secção de Obras d'O Estado de São Paulo. - São Paulo, 1927.

- Apelação n. 17.371, Tribunal de Justiça de São Paulo. Egidio Brasileiro França vs. José Pecora. - São Paulo Editora Litda. 1929.

- Renovação de registro de marca. - 0 caso da balança "Howe". - Emprêsa Gráfica da Revista dos Tribunais (São Paulo, 1929).

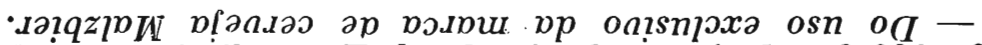
Supremo Tribunal Federal. Apelação civel n. 6.864. Companhia Antartica Paulista vs. Companhia Cervejaria Brahma. - Tip. do Jornal do Comercio. - Rio de Janeiro, 1938.

- Da citação “ad domum" e sua propriedade no caso Mendes Lima \& Cia. vs. Granja Coimbra. - Memorial do advogado Antiogenes Chaves. Graficos Bloch. - Rio de Janeiro, 1939.

- Embargos n. 6.643, da Capital. Tribunal de Apelação de São Paulo. - Memorial do advogado JoRGE DA Veiga. Emprêsa Gráfica da Revista dos Tribunais. São Paulo, 1940. 
- Embargos Civeis n. 5.869, Supremo Tribunal Federal, alegações do advogado Antonio Mercado Junior. Banca Francese e Italiana per l'América del Sud vs. Fazenda Nacional. - Emprêsa Gráfica da Revista dos Tribunais. São Paulo, 1939.

- Embargos Infringentes n. 1014. - Tribunal de Apelação do Rio Grande do Sul, Comarca de Porto Alegre. C. Torres \& Cia. vs. Alberto Torres. Alegações do advogado Oswaldo Vergara. Oficinas Gráficas da Livraria do Globo (Pôrto Alegre, 1939).

- Promessa de compra e venda. Fôro de Porto Alegre, Rio Grande do Sul. Alegações do advogado Guicerio Alves. Inácio Corrêa de Sá vs. Viuva Aristoteles Afonso Agra de Jesus. Ed. da Livraria do Globo. Porto Alegre, 1940 .

- $O$ direito de renovação do registro de marcas de fábrica e de comercio. - Supremo Tribunal Federal. Apelação n. 6.937. Razões dos advogados Lopes DA CostA. Enoch Morgan's Sons \& Co. vs. Cia. Produtos Quimicos. Fábrica Belém. - Emprêsa Gráfica da Revista dos Tribunais. São Paulo.

- Sociedades anônimas. Das ações ao portador; sua preexistência aos titulos que as representarão; sua subsistência independentemente desses títulos, enquanto não emitidos; sua circlação como coisa incorpórea, enquanto não emitidos os títulos. Alegações do advogado Luiz NazAreno DE Assumpção. São Paulo, 1945.

- Mandado de segurança requerido pela Companhia Antartica Paulista. - Estabelecimento Grafico Phoenix. São Paulo.

- Estas terras do rio Batalha. - Um grilo que a Justiça de Pederneiras faz questão de vitalizar. - Memorial dos advogados Milton Castro Ferreira \& Paulo Vale. - - 
Emprêsa Gráfica da Revista dos Tribunais. - São Paulo, 1948.

Existem ademais vários outros pareceres publicados pelos interessados em vários jornais do país.

Deputado federal por São Paulo, na legislatura de 1935 a 1937, e presidente da Comissão de Constituição e Justiça, teve WaLdemar Ferreira intensa atividade assim nesta Comissão como no plenário da Câmara dos Deputados. Discursos, pareceres, emendas, projetos, substitutivos e outros trabalhos parlamentares encontram-se nos vários volumes do Diário do Poder Legislativo daquêle triênio e nos respectivos Anais da Câmara dos Deputados. 